\title{
KERK EN OWERHEID, EN DIE RASSEVRAAGSTUK IN SUID
}

AFRIKA

\section{Die Interesse VAn die Kerk}

Dit gaan die Kerk in al die spreek en doen van sy bestaan op die aarde om die heil van die mense, alle mense, tot eer van God, die Vader van Jesus Christus, die God van die Bybel. Hy vervul sy verantwoordelikheid profeties, deur te getuig áán alle mense; priesterlik, deur voorbidding te doen, in te tree, vír alle mense; koninklik deur op die aarde te lewe in die vryheid van die kinders van God vóór alle mense. Hierdeur bevind hy hom nie op drie terreine los van mekaar nie, en verrig hy nie om die beurt drie take los van mekaar nie. Dit bly één taak en één gehoorsaamheid wat hy in drie dimensies verrig en vervul. Hy getuig byvoorbeeld nie vír waarvoor hy nie ook vrymoedigheid het om te bid, en wat hy nie ook ber eid is om te léwe nie. Sy profetiese taak, die verantwoordelikheid om te getuig, het altyd ook 'n priesterlike en 'n koninklike dimensie, en omgekeerd. Die kerk wat profeties eis waarvoor hy nie vrymoedigheid of geleentheid het om priesterlik in te tree nie, of wat hy nie bereid of in staat is om self koninklik te lewe nie, dien 'n ander doel as die heil van die mense of die eer van God.

Bybelse getuienis heet nou eenmaal marturein en dit kan nooit losgedink word van die risiko van martelaarskap, en die aanvaarding van hierdie risiko nie. 'n Kerk wat op die maklike manier getuig, dit wil sê op 'n afstand, van ver af, met ander woorde sonder die risiko om vir sy getuienis priesterlik, plaasvervangend, te sal moet instaan, en sonder die risiko om die resultate van sy getuienis koninklik, vorstelik, vreesloos, te sal moet verduur; so 'n kerk sal goed doen deur homself weereens af te vra waarom dit hom in sy getuienis gaan. Kan hy deur te getuig werklik die heil van die mense of die eer van God dien? Sou hy dié nie beter dien deur te swyg nie? Is sy spreke nie uiteraard gedoem om „maar woorde" te wees nie? Kan daar 'n tyd kom wanneer die taak van die kerk niks moeiliker sal wees as die onderskrywing van die menings van die wêreldpers nie?

Ook in die spreek en doen van die owerheid gaan dit om die heil van alle mense tot eer van God. Dit wéét die kerk beter en duideliker as die owerheid self. Daarom is die kerk intens gemoeid met die besigheid van die owerheid. Die kerk vervul sy verantwoordelikheid voor God nie, tensy hy steeds ook die owerheid oproep tot die allerbeste vervulling van sy, die owerheid se, taak onder die mense nie. Dit doen die kerk deur in sy soek na die heil van alle mense tot eer van God, profeties áán die owerheid te getuig, priesterlik vír die owerheid in te tree, koninklik, in die vryheid van die kinders van God vóór die owerheid te lewe. Omdat die heil van alle mense so onlosmaaklik verbonde is met die wyse waarop die owerheid sy taak vervul, juis dáárom is dit, hiér meer as wáár ook anders, van die uiterste belang dat die profetiese, die priester- 
like, en die koninklike optrede van die kerk ten opsigte van die owerheid, één optrede sal wees, dieselfde klank sal hê.

\section{Wat die Kerk van die Owerheid weet}

Die kerk weet van die owerheid méér as wat hy uiteraard van homself kán weet, wat hy alleen van die kerk te hore kan kry: dat hy nie 'n toevallige verskynsel is nie, maar 'n essensiële; dat hy nie 'n uitvindsel van die duiwel is nie, maar 'n geroepene van God; dat hy nie 'n god is wat maak soos hy wil nie, maar 'n dienaar van God wat verantwoording verskuldig is.

Pontius Pilatus sou geen ,mag" oor Christus gehad het as dit hom nie van die Vader gegee was nie. Hierdie ,mag", om te kan veroordeel en laat kruisig, is hom klaarblyklik gegee om sodoende, sonder dat hy dit weet of vermoed, mede-diensbaar te wees in die verlossing van die mense. Terwyl hy meen dat hy heers, dien hy die heilsplan van God. En die heidense Romeinse Ryk, - in die dae van die Nero-bewind! is 'n dienaar van God die gelowiges ten goede! (Rom. 13:4.)

Dis opvallend hoe dikwels die owerhede en magte hulle in die Nuwe Testament in die omgewing van die ,engele” bevind. „Engele, owerhede, en magte", is byna 'n staande uitdrukking. Vir die Bybelse gedagtewêreld is die engele dienende geeste van God, diensbaar in die bewerking van die heil van die mense. In die wêreld van hierdie dienende geeste bevind vir die geopenbaarde geloofskennis van die Bybel, die owerhede en magte hulle ook. Die kerk weet dat die owerheid daar is omdat God hom, die owerheid, in die proses van die voltooiing van sy God se - heilswerk aan die mense, wil gebruik. Die kerk het die versekering dat aan Christus gegee is alle mag in hemel en op aarde. Mat. 28:18. En nou is daar geen mag (owerheid) behalwe van God nie, en die wat daar is, is deur God ingestel. (Rom. 13:1.)

Die kerk weet egter ook, ondanks die twyfellose versekering dat Christus ,,die owerhede en magte uitgeklee (dit wil sê van hulle opgesmukte selfverheerliking ontdaan het), en hulle in die openbaar ten toon gestel en daardeur oor hulle getriomfeer het", (Kol. 2:15), dat die owerhede en magte hierdie triomf allermins resloos aanvaar het. Hulle het hulle nie daarby neergelê nie. Die triomf wat onherroeplik behaal is, moet nog finaal beklink word. Tot dan bevind die owerhede en magte hulle nog in die geselskap van ,die wêreldheersers van die duisternis van hierdie eeu, die bose geeste in die lug." (Ef. 6:12.) Die kwessie van die verwantskap tussen demoniese magte ",in die lug", en konkrete aardse owerhede, hoef nie hier verder uitgepluis te word nie.

Daar is immers ook gevalle engele. Die God van die liefde is uiteraard ook die God van die vryheid. Juis dáárom staan vir sy dienaars ook die skrikwekkende moontlikheid van rebellie steeds oop. So 'n gevalle engel, 'n rebellerende dienaar van God, 'n selfverheerlikende teenstander van God, 'n self-opgewerpte teen-god, is die duiwel. En alhoewel hy weet, juis omdat hy weet dat sy lot verseël is, rus hy nie, maar „loop 
hy rond soos 'n brullende leeu en soek wie hy kan verslind." (I. Pet. 5 :8.) En nêrens vind hy so 'n kwesbare prooi om te kán verslind as die owerhede en magte nie. Niemand is vir die versoeking om te rebelleer, om self god te wil word, so vatbaar as die owerheid nie. Daarom ken en teken die Bybel ook die afgryslike prent van die owerheid wat 'n gevalle engel geword, homself usurperend in die plek van God geplaas het. (Openb. 13.) Van hom geld: „Hy maak sy mond oop om te laster teen god, om sy Naam en sy tabernakel en dié wat in die hemel woon, te laster. Dit is ook aan hom gegee om oorlog te voer teen die heiliges en hulle te oorwin, en aan hom is mag gegee oor elke stam en taal en nasie. En al die bewoners van die aarde sal hom aanbid ..." Die Bybel weet dus ook dat daar op die aarde niks so suksesvol as sukses is nie.

Die kerk weet ook dat die owerheid, elke owerheid, vir hierdie moontlikheid blootstaan. En die kerk het ondervind, wat hy trouens reeds uit die Woord van die Here kón weet, dat 'n "Christen-owerheid" vir hierdie skrikwekkende moontlikheid nie minder blootstaan as 'n ,heidense owerheid" nie. Die kerk het naamlik deur die eeue van sy bestaan geleentheid gehad om kennis te maak met die owerheid van sowel „die vyf Goeie Keisers" van Rome (wat heidene was) as die vorste van Frankryk in die dae van die Kerkhervorming (wat Christene was). Ook die owerheid van 'n gelowige volk kan op 'n kwade dag skuldig word aan usurpasie, vir hom toe-eien wat aan God toekom.

Daarom is die kerk beveel om vir die owerheid, elke owerheid, te bid. En daarom vra die kerk van die owerheid, elke owerheid, nie 'n geloofsbelydenis nie, maar goeie politiek. Hieroor later meer.

Die kerk weet dus ten slotte van 'n voortgaande onderwerping van die owerhede en magte aan Hom aan Wie alle mag in hemel en op aarde gegee is. Eers by ,die einde, wanneer Hy die koninkryk aan God die Vader oorgee, is alle heerskappy en alle gesag en mag opgehef;" „onttroon", vertaal die Nederlandse Bybelgenootskap, dit wil sê van die troon waar ' $n$ heerser hom bevind, afgeroep, en geplaas in sy regte posisie, die van 'n dienaar. (I Kor. 15:24.)

In hierdie proses, deel, belangrike en onontbeerlike deel, van die voorbereiding van die koms van die koninkryk van die hemele, is die kerk, die liggaam op die aarde van Hom aan Wie alle mag in hemel en op aarde gegee is, mede-diensbaar. Hy wat die onderwerping van die magte eenmaal bewerk het, en nou besig is om sy oorwinning te konsolideer, verkies om dit te doen deur op die aarde Hom te bedien van die diens van hierdie liggaam, die kerk. In hierdie verband verrig die kerk sy diens deur profeties áán die owerheid te getuig, priesterlik vír die owerheid in te tree, koninklik vóór die owerheid te lewe. Só word die owerheid voortdurend herinner aan - en gewys op - sy verantwoordelikheid voor God. Dit is 'n verantwoordelikheid nie om te bely nie, maar om goed te regeer. Om te bely is die taak van die Kerk.

So verneem volk en owerheid van die Kerk die tyding van Jesus 
Christus wat die Voleinder is óok van die owerheid se bemoeienis om die heil van die mense.

\section{Kerk en Owerheid „BymekaAR”}

Omdat die kerk weet van die roeping van die owerheid in die diens van Christus, en omdat die kerk weet van die onontbeerlikheid van die diens van die owerheid vir die uitvoering van sy, - die kerk se - eie taak in die diens van daardie selfde Meester, dáárom is die kerk primêr en prinsipieël vír die owerheid, vír elke owerheid. Vir die kerk is enige owerheid hoegenaamd, verkiesliker as geen owerheid nie. Dit gaan om die heil van die mense.

Van die kerk se kant af bestaan daar in elk geval verwantskap met die owerheid, enige owerheid. Vir die kerk is die owerheid, enige owerheid, steeds 'n kameraad — vir wie die kerk dankbaar is — in diens van dieselfde Heer. ${ }^{1}$ )

Bestaan hierdie verwantskap van die owerheid se kant af ook, met ander woorde is die kerk ook vir die owerheid 'n kameraad, vir wie die owerheid dankbaar is, in die diens van daardie Heer, dan dank die kerk die Here daarvoor. Is dit egter van die owerheid se kant af anders, is die kerk vir die owerheid 'n vreemdeling wie se woord hy nie hoor nie, dan eers terdeë vervul die kerk sy verantwoordelikheid teenoor hierdie owerheid voor God deur geheel en al en resloos en onvoorwaardelik vír hierdie owerheid te wees. Ongetwyfeld sal sy vir-die-owerheid-wees dán - maar ook andersins -- wanneer dit móét, nie aarsel om die vorm aan te neem van vreeslose kritiek op die dade of voorgenome dade van so 'n owerheid nie. Egter só, en só alleen, dat juis dít dan die hoogste openbaring is van die feit dat hy vír die owerheid is; presies soos God nooit en nêrens só vír die sondaar is as juis deurdat en in soverre $\mathrm{Hy}$ meedoënloos téén die sonde is nie. Nooit mag die kerk se optrede nalaat om méér te wees as wat 'n opposisieparty ook kon doen nie.

Dit, hierdie prinsipiële vir-die-owerheid-wees, lê seker opgesluit in die uitspraak van Jesus, (Mark 12:17 en paralelle): „Betaal aan die keiser wat die keiser toekom ..." Hierdie eerste helfte van sy uitspraak is vir die Fariseëıs onder sy ondervragers, bekend vir hulle prinsipiële teen-die-owerheid-wees, netso 'n skerpe teregwysing as wat die tweede helfte van die uitspraak: „en aan God wat God toekom," dit is aan die Herodiane onder sy ondervragers, ewe bekend vir hulle slaafse onderhorigheid aan die owerheid. Van groot belang is die feit dat Jesus sy antwoord - tog klaarblyklik doelbewus - só formuleer dat dit vir die keiser meer opeis as die blote belastings waarvan in die vraag sprake was.

Dieselfde eis sal ook die volle inhoud wees van die ,,doen wat goed is", wat Paulus in Rom. 13:3 eis, en waarvoor die owerheid lof sal hê.

1) Karl Barth, Rechtfertigung und Recht, Theologische Studien Heft I, Zürich o.J., S. 39: Buite die kerk is daar geen plek in die wêreld waar ' $n$ fundamentele kennis van die bestaansreg en die nooduendigheid van die staat bestaan en uitgespreek word nie . . (vertaling van $\mathrm{my}$ ). 
Of sou daar werklik 'n plek wees waar ,,doen wat goed is" vir die Bybel niks méér inhou as die weerhouding van strafbare misdadigheid nie?

En dieselfde eis gee ook betekenis aan die ,,alle mense" van I Tim. 2:1 vlg. ,Konings en hooggeplaastes", dit wil sê owerhede, is hoofsaaklik verantwoordelik vir die handhawing van 'n stil en rustige lewe, waarvoor voorbidding gedoen word. Maar klaarblyklik is alle mense hiertoe 'n bydrae skuldig, 'n bydrae so belangrik dat die kerk beveel is om onvoorwaardelik en voortdurend te bid dat dit nie sal uitbly nie. En allermins sal die kerk wat hiervoor moet bid, van die verantwoordelikheid vir hierdie bydrae onthef wees.

Omdat die eis dat die kerk prinsipieel en konsekwent vir die owerheid, vir elke owerheid, sal wees, inderdaad "'n harde woord" is, daarom het die kerk die blye versekering dat „Hy wat as Hoof bo alle dinge aan die gemeente gegee is, sit bo alle owerheid en mag en krag en heerskappy en elke naam wat genoem word, nie alleen in hierdie wêreld nie, maar ook in die toekomstige". (Ef. 1:21 \& 22.) Die kerk weet dat hy saam met die owerheid ,,in één span trek", en dat die owerheid nie anders kan as om, hoe ookal, mede-diensbaar te wees vir die uitvoering van die taak wat die kerk opgelê is, en waarvan die afloop in Christus reeds gewaarborg is nie.

Die bewussyn by die Kerk dat kerk en owerheid onder alle omstandighede bymekaar hoort, kon in die 19 eeue wat sedert die N.T. tyd verloop het, slegs essensiëler geword het. Immers in die outokratiese wêreld waarin die geskrifte van die N.T. ontstaan het, het die gelowiges aan wie hierdie eis gestel is, geen medeseggenskap hoegenaamd in owerheidsake gehad nie. In die demokratiese wêreld waarin die huidige betoog wil spreek, is elke gelowige 'n potensiële owerheidmaker.

Wie hierdie onontwykbare verbondenheid van die kerk se kant af tussen kerk en owerheid ontken of uit die oog verloor, raak in die diskussie oor kerk en owerheid onvermydelik op 'n dwaalspoor. Hy verlaag die kerk tot professionele foutvinder. ${ }^{2}$ ) Dan loop die kerk beterweterig en onverantwoordelik agter die owerheid aan om aan elke daad van die owerheid 'n etiket te steek: Dis verkeerd, dis sleg, dis boos. Om dit te doen, is geen kuns nie, en daarmee is die heil van die mense nie watwonders gedien nie. Enige owerheid sou dwaas wees om hom daaraan te steur.

Is dit hoegenaamd moontlik om agterna PROFETIES te getuig? Waaruit moet sulke profetiese getuienis dan bestaan? Blote oordeelsaankondiging? Dié mág seker op sy plek en ook onvermydelik wees, maar dan, in die naam van Christus, seer seker nóóit sonder die belofte van vergewing op bekering, plus daarby die aanduiding van waarin dié bekering sal bestaan nie. Ten opsigte van die rassevraagstuk in S.A. is daar on-

2) Vgl. Die Hervormer, Sept. 1960, bls. 13: Nou is dit nie my taak as predikant om politieke beleidsrigtings uit te werk nie. Dit is die werk van die mense wat dáárvoor daar gestel is. As predikant mag en moet ek egter beleidsrigtings toets aan die Skrif. 
gelukkig ook Jona's wat niks méér haat as die gedagte dat die aangekondigde oordeel dalk afgewend mag word nie!

Tereg stel van Niftrik $^{3}$ ): „,De kerk moet toezien dat zij niet altijdnet even te laat komt, of wacht tot haar beslissing geen risico meer betekent." En van Ruler ${ }^{4}$ ) formuleer positief: „Te zeggen dat de kerk alleen kritisch, alleen negatief, getuigt, dat zij alleen haar stem verheft, als het in die wereld, byvoorbeeld in den staat, den verkeerden kant uitgaat, is apert onjuist. In ieder geval moet men ook zeggen, dat de kerk ook vormend, ook positief getuigt, dat het haar recht en haar plicht is om aan te geven, niet alleen hoe het niet moet, maar ook hoe het wel moet. En dat is zelfs nog niet genoeg. De kerk laat het niet by een zeggen. $Z$ ij gaat ook aan den slag en neemt ook zelf de ordening van het leven ter hand..."

Eers só bevind die kerk hom met sy diens aan owerheid en volk op profetiese vlak, verkondig hy met krag, loop hy nie meer foutvinderig agter die owerheid aan nie, maar gelowig voor die owerheid uit, besig om, in die geloof, vanuit die toekoms, die lewe op die aarde te vorm in die gestalte van die geloof. Dit is die volle hoogte en die volle diepte van die "doen wat goed is" van Rom. 13:3.5 Niks het die owerheid, vir sy voortbestaan as dienaar van die God van die kerk, nodiger as dít nie. En nêrens anders as by die kerk kan hy dít kry nie. Kritiek en veroordeling kry hy volop. Maar verder sien en duideliker hoor as waartoe die politiek in staat is, kan alleen die kerk.

Die kerk in Suid-Afrika het reeds in die 18de eeu, meer as 'n eeu voor die aanvang van Christelik-Wes-Europa se berugte „Scramble for Africa", begin om aan Owerheid en volk 'n samelewingspatroon vir Blank en nie-Blank voor te lewe; en in die 19de eeu voor uitheemse én inheemse owerhede in S.A. vir daardie patroon begin getuig; en in die 20 ste eeu bereik dat die handhawing van hierdie samelewingspatroon owerheidsbeleid geword het. Dít moet baie duidelik gesê word: Eiesoortige ontwikkeling vir Blank en nie-Blank is nie in 1948 deur die owerheid uitgedink vir die kerk om te kritiseer nie. Eiesoortige ontwikkeling is deur die kerk as die enigste moontlike permanente samelewingspatroon vir Blank en nie-Blank in hierdie land as hoorbare én sigbare getuienis aan owerheid en volk vóórgelewe op 'n tydstip in die geskiedenis toe „,kleurvraagstuk" vir die res van die wêreld nog 'n onbekende woord was.

\section{Kerk en Owerheid „TeenoormekaAR”}

Eers nadat dít, die noodwendige ,,bymekaar" van kerk en owerheid, duidelik geponeer is, kan Oscar Cullmann ${ }^{6}$ ) se formulering van die taak van die kerk sonder meer aanvaar word: , . . . it has to fulfil the office

3) G. C. van Niftrik, Een beroerder Israels, Nijkerk 1948, bl. 304.

4) A. A. van Ruler, Religie en Politiek, Nijkerk 1945, bl. 177.

5) Vgl. Karl Barth, a.a.O., S. 45.

6) O. Cullmann, The State in the New Testament, London 1957, p. 90. 
of watchman over the state. That means it must remain in principle critical toward every state and be ready to warn it against transgression of its legitimate limits. (And) it must deny to the state which exceeds its limits whatever such a state demands that lies within the province of religio-ideological excess; and in its preaching the church must courageously describe this excess as opposition to God."

Juis hierdie teenoor-die-owerheid-staan in die reële vryheid van diegene wie se ,burgerskap in die hemel is”, maak van die vir-die-owerheid-wees van die kerk méér as politieke ondersteuning. Die vir-dieowerheid-wees, soos die teenoor-die-owerheid-staan van die kerk, het met ondersteuning aan, of teenkanting teen, die politieke party wat op 'n bepaalde tydstip bewind voer, niks te make nie. Die kerk spreek in die party-politiek in, nooit daaruit nie. Die kerk dien nie partybelange nie, maar die heil van alle mense. Hierdie diens verrig hy in gehoorsaamheid aan dié Heer alleen wat ook die Heer van die owerheid is. Sodoende lewer hy ook aan die owerheid dié diens wat die owerheid van geen ander oord kan ontvang nie, en wat tog vir sy voortbestaan, en vir die uitvoering van sy Godgegewe taak onontbeerlik is. Tegelyk koninklik vóór die owerheid staan, profeties teenóór hom staan, en tog priesterlik geheel en al en resloos by hom staan, kan geen ander instansie ter wêreld nie. Hierdie diens ontrang die owerheid alléén van die kerk.

Om hierdie rede word die bo-aangehaalde taakstelling van Cullmann ook onmiddellik voorafgegaan deur die onvoorwaardelike eis: „It must loyally give the state everything necessary to its existence. It has to oppose anarchy and all Zealotism (sabotasie van die owerheid) within its own ranks." Eers wanneer die owerheid geen oomblik meer hoef te twyfel dat juis die teenoor-hom-staan van die kerk die suiwerste uiting van die vir-hom-wees van die kerk is nie; met ander woorde dat wat hy hier te hore kry, uit ander oorwegings as ,die vrees van diegene wat kwaad doen" (Rom. 13:4) spruit; eers dán mag die kerk verwag dat die owerheid sal onderskei tussen wat hy hiér verneem en wat hy elders ook te hore kon kry.

Ten opsigte van die situasie in Suid-Afrika beteken dit dat die kerk wat oortuig is dat eiesoortige ontwikkeling die samelewingspatroon is wat die heil van alle mense die beste dien; omdat dit, van alle moontlikhede, vir die behoud van 'n sterk en stabiele owerheid die bevorderlikste is; dáárvoor vreesloos sal getuig; maar dan terselfdertyd ook vreesloos en onverpoosd sal aandring op 'n eerlike onder-die-oë-sien van die konsekwensies en 'n onverbiddelike aanvaarding van die implikasies van die samelewingspatroon waarvóór hy getuig. Daar is naamlik nog bedroewend-veel Blankes, lede van die volk, én lede van die kerk, maar ook draers van die owerheid, wat eiesoortige ontwikkeling steun omdat hulle meen dis 'n metode om „Blanke baasskap" te beveilig en ,gelykstelling" te verhoed. Hier móét die kerk duidelik en onomwonde getuig dat dié samelewingspatroon wat hy voorstaan, bedoel om op 'n vreedsame wyse 
baasskap te beëindig en gelykstelling te verwesenlik. Wie dit andersom wil, moet die kerk vreesloos proklameer, pleeg ,,opposition to God”.

Daarby sal die kerk voortdurend by die owerheid moet aandring op onvermoeide ywer in die soek na die allerregverdigste en allerbillikste metodes in die toepassing van die beleid wat hierdie samelewingspatroon wil werklikheid maak; dat rassevermenging op so 'n wyse aan bande gelê en uiteindelik beëindig word dat die leed wat die vermenging reeds veroorsaak het, deur die beëindiging daarvan nie vermeerder nie, maar verminder sal word.

En terselfdertyd sal die kerk by die volk, Blank sowel as nie-Blank, voortdurend aandring op die bereidheid om, ter wille van die heil van alle mense, dié offers aan persoonlike gemak en gerief en geluk te bring wat die verwesenliking van hierdie samelewingspatroon in die huidige situasie nou eenmaal verg; dat die taak van die owerheid nie bemoeilik nie, maar vergemaklik word. Die kerk móét waak teen skending van die reg van die nederigste mens, maar die kerk mág nooit selfsug as 'n deug aanprys nie.

\section{Wat die Kerk van die Owerheid eis}

Die kerk verlang nie van die owerheid opname van Bybeltekste of dogmatiese uitsprake in sy wetgewing nie. Die owerheid gee nie gestalte aan die evangelie nie. Dit doen die kerk. Die owerheid beskik nie oor die middele daartoe nie. Die Heilige Gees en die verkondiging van die Woord is aan die kerk gegee. Die owerheid besit net die swaard. En dié is vir die uitdra van die evangelie onbruikbaar. Die belydenis van die vaders in dié verband (Ned. Geloofsbelydenis, Art. XXXVI) ontbeer skriftuurlike grond, spruit uit die toevallige historiese situasie van 'n vervloeë tyd, en verdien hersiening.

Wat die kerk van die owerheid verlang, en van hom mag en moet eis, is doodgewone goeie politiek. „Politieke beslissingen kunnen niet door hun Christelijke fundering, maar alleen daardoor dat zij politiek béter, tot handhaving en opbouw van de gemeenschap heilzamer zijn, duidelijk gemaakt worden." ") Vir die beoordeling van die politiek het die kerk 'n duidelike en onmiskenbare maatstaf ontvang. Goeie politiek is vir die kerk dié politiek waarvoor die kerk beveel is om te bid, naamlik politiek wat daartoe lei ,,dat ons 'n rustige en stil lewe kan lei in alle godsvrug en waardigheid. Want dit is goed en aangenaam voor God, ons Verlosser, wat wil hê dat alle mense gered word en tot kennis van die waarheid kom." (I Tim. 2:2-4). Hierdie Bybelwoord noem Karl Barth, ${ }^{8}$ ) van al die vermaninge wat in die Nuwe Testament aan die Christene aangaande hulle verhouding tot die owerheid gegee word, ,die intiemste en tegelyk al die ander omvattende en radikaliserende."

En hierin gaan die om WET EN ORDE op die aarde! Dít is wat die owerheid voor enigiets anders aan die mense verskuldig is. Dit is wat

7) G. C. van Niftrik, a.w., bl. 303.

) K. Barth, a.a.O., S.34. 
die kerk voor enigiets anders van die owerheid mag en moet eis. Dat daar ,'n stil en rustige lewe" op dié aarde waar die sonde nog so welig tier, moontlik sal wees, is vir die Bybelse realisme alles behalwe vanselfsprekend. En omdat die voorsiening hierin die hoë en geweldige taak van die owerheid is, maar ook omdat die heil van alle mense so intens hiermee gemoeid is, daarom moet die kerk ,,smekinge, gebede, voorbedes, danksegginge vir alle mense, vir konings en almal wat hooggeplaas is", beoefen.

Wet en orde, die moontlikheid van ,'n rustige en stil lewe", is naamlik, so konstateer die Bybel, die aller-essensieëlste vereiste vir die voortgang van die evangelie. Ook in die tweede helfte van die twintigste eeu sal die kerk nie anders kan as om hom deur die Bybel te laat sê dat wet en orde die voortgang van die evangelie beter dien as chaos en anargie nie. En wie die voortgang van die evangelie eerste oorweging maak, sal enigiets verkiesliker vind as chaos en anargie. Vir die kerk moet die vooruitgang van die evangelie, ,dat alle mense gered word en tot kennis van die waarheid kom", nie die eerste nie, maar die enigste oorweging wees. Daar is ook ander instansies met ander oorwegings, vir wie chaos en anargie voordelig is. Hulle mag nie in die kerk praat nie, en ook nie déur die kerk nie, en hulle meedoënlose uitroeiing MOET die kerk van die owerheid eis; want die kerk weet dat die owerheid daar is om wet en orde te handhaaf-met die swaard as dit moet!

Is daar in die tweede helfte van die twingste eeu 'n plek in die wêreld waar die kerk met meer oortuiging as op die suidpunt van Afrika, van die owerheid, in die aangesig van watter teenstand ook, onvoorwaardelik dié politiek moet eis wat vir die handhawing van wet en orde, vir die behoud van 'n rustige en stil lewe, die bevorderlikste sal wees?

Wet en orde kan op twee maniere gehandhaaf word. Rus en stilte kan twee karakters hê. Die owerheid kan vir die bereiking van sy doel twee weë bewandel. Die maklike manier is om dit te bewerk deur skrik en vrees. Dan dra die stilte en rus wat heers, die karakter van veronregting en slawerny. Dié bedoel die Bybel nie! Daarom is die ,rustige en stil lewe" waarvoor die kerk beveel is om te bid, ook nader gekwalifiseer. Dit moet naamlik 'n rustige en stil lewe wees, nie in vrees en slawerny nie, maar ,,in alle godsvrug en waardigheid." (I Tim. 2:2.)

Vir die kerk het hierdie woorde konkrete betekenis. Die kerk weet dat in Jesus Christus elke mens geroepe is om 'n geregverdigde en 'n vrygemaakte te wees in die geloof. Die kerk weet ook dat elke mens potensieël 'n geroepene is om op die aarde gestalte te gee deur die Heilige Gees aan die geregtigheid en die vryheid wat hy as geskenk in die geloof besit. Die kerk weet dat mens-wees, mens-wees na die bedoeling van God, 'n sekere reg en 'n sekere vryheid vir elke mens beteken. Sonder hierdie reg en vryheid is daar van 'n lewe in godsvrug en waardigheid geen sprake nie, bly daar net nog die stilte en rustigheid van slawe oor.

Dat die owerheid hiertoe in staat sal wees, is deel van die inhoud van die voorbidding van die kerk. Die kerk verwag van die owerheid 
daarom ten tweede die beskerming van die REG EN VRYHEID van die mense.

In sy verwagting van die beskerming van die reg en vryheid van die mense deur die owerheid, ${ }^{9}$ ) laat Karl Barth hierdie selfstandige naamwoorde steeds voorafgaan deur die byvoeglike naamwoord ,relatief”, en kwalifiseer hy hierdie byvoeglike naamwoord ook nog meermale met die bywoord „hoogs”. Hoe kan dit anders? Ons leef immersook as ons gelowiges is-nog in 'n sondige wêreld, waar vryheid en verantwoordelikheid, reg en plig helaas-ook vir die gelowiges-nog nie sinonieme is nie; en waarin daar daarom nog steeds botsende regte en botsende vryhede voorkom, die reg en die vryheid van die een altyd weer ' $n$ bedreiging vir die reg en die vryheid van die ander word. En in so 'n wêrreld verwag en eis die kerk van die owerheid die beskerming van die reg en die vryheid VAN ALLE MENSE. Die kerk weet terwyl hy dit van die owerheid eis, dat juis dit wat hy eis, die ontsegging aan alle mense beteken van enige reg en enige vryheid wat ' $n$ bedreiging sal inhou vir die reg en die vryheid van één indiwidu. Dit beteken nou eenmaal die afdwinging-met die swaard as dit moet-van die verantwoordelikheid en die plig van sommiges. Daar is op hierdie aarde nou éénmaal alleen soveel reg en soveel vryheid as wat die reg en die vryheid van iemand anders nie in gevaar stel nie. Voorwaar, die reg en die vryheid wat die owerheid kan bewerkstellig, kan hoogstens ,hoogs relatief" wees.

Maar dit, die relatiewe reg en die relatiewe vryheid van alle mense, van die Blankes én die nie-Blankes in Suid-Afrika, en die beskerming daarvan ook vir die toekoms, mag en moet die kerk van die owerheid eis. Politiek wat na die mening van die kerk ' $n$ bedreiging inhou vir die verbestendiging van die reg en die vryheid van óf die Blankes of nie-Blankes, in die hede of in die toekoms, móét die kerk as slegte politiek veroordeel.

'n Staat waarin die owerheid die handhawing van wet en orde oorbeklemtoon, bied uiteindelik die skouspel van die ongelooflik-gedissiplineerde en bomenslik-presterende Nazi-Duitsland of Kommunistiese Rusland. 'n Staat waarin die owerheid die beskerming van die reg en vryheid van die mense oorbeklemtoon, bied uiteindelik die chaotiese skouspel van die Franse Rewolusie of die Belgiese Kongo van 1960. Nie een van hierdie uiterstes dien die voortgang van die evangelie nie. Daarom mag en moet die kerk getuig dat nie een van hierdie uiterstes ,goed en aangenaam voor God, ons Verlosser (is) wat wil hê dat alle mense gered word" nie. En daarom eis die kerk ten slotte van die owerheid DIE BEHOUD VAN DIE EWEWIG tussen wet en orde enersyds en reg en vryheid andersyds.

Maar juis dít maak die maatstawwe ter beoordeling van die politiek wisselend en relatief. Daar is alleen soveel reg en vryheid moontlik as

9) G. C. van Niftrik. a.w., Hoofstuk VIII. 
wat die behoud van wet en orde nie in gevaar bring nie. En alleen soveel wet en orde is wenslik as wat die relatiewe reg en vryheid van die mense nie onnodig skaad nie. Wáár die grens lê, wissel na gelang van die plek, die tyd en die situasie. Daarom bestaan daar soiets as die afkondiging van 'n noodtoestand en die promulgering van noodmaatreëls. Geen verantwoordelike owerheid durf hiervoor terugdeins nie. En geen verantwoordelike kerk durf hiermee foutvind nie.

Juis die dialektiek van die handhawing van wet en orde enersyds en die beskerming van reg en vryheid andersyds, maak van die politiek so 'n existensieël-riskante besigheid. Die heil van alle mense is daarby op die spel. Beoordeling daarvan deur die kerk verg telkens 'n geloofsbeslissing. Maar juis daarom is die Godgegewe opdrag van die kerk ten aansien van die owerheid ook nie om hom te stenig nie, maar om vir hom te bid.

Behalwe die kerk is daar nêrens in die wêreld 'n plek waar die werklike omvang en verantwoordelikheid van die taak van die owerheid besef word nie. Want alleen die kerk ken die werklike mag van die sonde op die aarde. ${ }^{10}$ ) Daarom mag die kerk allermins maklike en reglynige slagspreuke die maatstaf ter beoordeling van die politiek mak. En wie Suid-Afrika ken, wéét dat so 'n beoordeling hiér alleen die grofste onverantwoordelikheid openbaar.

Goeie politiek vir die kerk word dáár beoefen waar die owerheid van stap tot stap in volle verantwoordelikheid vir die hede en die toekoms, dié beslissings fel wat dapper genoeg is om te verhoed, met die swaard as dit moet, dat die hoogstens ,hoogsrelatiewe reg en vryheid van die mense" die voortbestaan van wet en orde ophef; en selfbeheersd genoeg om te verhoed dat wet en orde 'n magsmonster word wat die relatiewe reg en vryheid van die mense vernietig. Sulke politiek eis die kerk van die owerheid.

Daar is beweer dat hierdie standpunt, die aandrang op die behoud van die ewewig tussen wet en orde enersyds en reg en vryheid andersyds, die gelykstelling beteken van ,,afgode en gode". Wet en orde is dan afgode en reg en vryheid is wettige gode. Hierdie kritiek beteken dan dat wet en orde die dienaar is van reg en vryheid, maar dat reg en vryheid ontslaan word van die verpligting tot eerbied vir wet en orde. Sulke kritiek weerspieël die geestesklimaat van die tweede helfte van die twintigste eeu, met sy „Bill of human rights" en sy aandrang op „Life, liberty and the pursuit of happiness", sonder enige sprake van verantwoordelikhede, perfek. Maar die dag wanneer sulke kritiek uit die kerk voortkom, is voorwaar 'n kwade dag. Die kerk weet immers dat gode, juis wanneer

10) Daar sit geweldige teologiese diepsinnigheid in die uitspraak van Sir Winston Churchill, wat volgens ' $n$ koerantberig by geleentheid verklaar het: In politics it is never a question of choosing between good and bad, but always of choosing between bad and worse; and it is of paramount importance that we shall every time choose the bad. Hierdie man het kennis geneem daarvan dat die wêreld waarin die politiek opereer, 'n sondige wêreld is, daarom weet hy van die relatiewe betekenis wat goed en sleg, soos reg en vryheid, in die politiek moet hê. Die kerk sal moet ophou kerk wees om die teendeel hiervan te kan beweer. 
en omdat hulle tot die rang van wettige gode verhef is, veel gevaarliker afgode is as wat enige afgod ooit kan wees. Op daardie dag het die kerk geen dringender en grimmiger verantwoordelikheid as om hierdie ,gode" meedoënloos te lyf te gaan, hulle in hulle naakte monsteragtigheid as duiwelse afgode te ontmasker, en hulle verering as ,,vervloekte afgodery" te veroordeel nie!

Voorop in die voorbidding van die kerk vir die owerhede, ter wille van ,alle mense", staan nou éénmaal nie ongebreidelde vryheid en bandeloosheid nie, maar ,'n stil en rustige lewe IN ALLE GODSVRUG EN WAARDIGHEID"!

\section{Wat die Kerk aAN die OWerheid verskuldig is}

Hierdie opskrif is doelbewus anders geformuleer as die vorige. Daar: „Wat die kerk van die owerheid eis”. Hier nie: ,Wat die owerheid van die kerk eis" nie. Dis owerheid eis van die kerk niks. Die owerheid ken alleen sy onderdane, sonder onderskeid en sonder uitsondering. En van hulle eis hy gehoorsaamheid. Wat die kerk as kerk aan die owerheid verskuldig is, is nie wat die owerheid van hom eis nie, maar wat God van hom eis. En die owerheid luister na die getuienis van die kerkas hy daarna luister-nie omdat die kerk die Bybel in die hand het nie, maar omdat hy uit ondervinding weet, dat hierdie groep van sy onderdane oor ' $n$ wysheid en ' $n$ helder blik vir die heil van alle mense beskik wat elders nie ge-ewenaar word nie. Dat hierdie wysheid en hierdie helder blik vir die heil van alle mense uit die Bybel kom, weet hy nie, en dit interesseer hom nie. En in sy beoordeling van hierdie getuienis vra hy nie: „Staan dit in die Bybel?" nie, maar: ,Is dit goeie politiek?"11)

Aan die owerheid is die kerk die oproep tot die beoefening van goeie politiek na die maatstaf aan die kerk gegee, verskuldig. Hierdie oproep sal steeds ook insluit die onthulling van die slegte politiek van die owerheid as slegte politiek na daardie maatstaf, omdat dit óf die behoud van wet en orde, óf die voortbestaan van die reg en vryheid van alle mense in gevaar stel. Hierdie getuienis van die slegtheid van sulke politiek kan dan-en móét dan ook-eventueel die vorm aanneem van die weiering van gehoorsaamheid aan sulke slegte politiek.

Aan die owerheid wat goeie politiek in bogenoemde sin beoefen, met voldoende ruimte gelaat vir die relatiewe betekenis wat "goed" nou éénmaal hier moet hê, ${ }^{12}$ ) is die kerk die oproep aan alle mense, en daarom seker in allereerste instansie aan homself, verskuldig: „Laat elke mens hom onderwerp aan die magte wat oor hom gestel is ..." (Rom. 13:1.) Hoe relatief die betekenis van ,goed" in die uitdrukking ,goeie politiek" in hierdie verband is, hoe 'n lang pad die kerk sal moet bewandel voordat hy daartoe kom om hom teen die politiek van die owerheid as ,slegte politiek" te verset, blyk uit 'n bestudering van die geskiedenis van die konings van Israel en Juda in die Ou Testament.

11) Vgl. G. C. van Niftrik, a.w., bl. 303.

12) Vgl. noot 10 . 
Eers Agab verbeur die sacro-sanctitas, die onaantasbaarheid, van die „Gesalfde van die Here", en dit nie vóór hy daartoe kom om Nabot se wingerd te vervreem, nie uit enige gegronde of denkbeeldige oorweging ter behoud van wet en orde of ter beskerming van die reg en vryheid van alle mense nie, maar wel uitdruklik ter skaamtelose bevrediging van eie hebsug! Tot op daardie stadium - en weer daarna - was die politiek van die konings, ondanks die eentonige reëlmaat van die mededeling dat hulle ,gedoen het wat verkeerd was in die oë van die Here", klaarblyklik steeds as "goeie politiek" op gehoorsaamheid geregtig. Die Bybel weet dat enige owerheid nog steeds verkiesliker as chaos en anargie is, en daarom as seëning uit die hand van die Here dankbaar aanvaar moet word, en daarom dan ook 'n geregverdigde aanspraak op gehoorsaamheid, „onderwerping”, van ,elke mens" het. En wat die Bybel weet, moet deur die kerk in die wêreld hoorbaar gemaak word.

Aan die owerheid is elke mens, so verneem die kerk in Rom. 13:1, „onderwerping" verskuldig. Daar is in die eerste twee verse van Rom. 13 'n woordspeling in die Grieks wat in enige moderne taal alleen ten koste van die vlotheid van styl weergegee kan word, en daarom in die vertalings omtrent totaal verlore gegaan het. Nie minder as vier verskillende samestellings of afleidings van die werkwoord tasso kom in hierdie twee verse voor nie. Van hierdie werkwoord in die grondbetekenis , in 'n bepaalde orde opstel", ,,aan iets of iemand sy bepaalde plek in 'n groter geheel aanwys". Die Afrikaanse woord wat die beste hier gebruik kan word, is "rangskik". Met gebruikmaking van hierdie werkwoord, staan daar in Rom. 13:1 en 2 dan letterlik min of meer die volgende: „Laat elke mens hom aan die magte wat hy oor hom het, onder-inrangskik, (hupo $=$ onder + tasso) want daar is nie 'n mag nie of hy is onder (hupo) God, en die wat daar is, is onder (hupo) God ingerangskik; (tetagmenai van tasso) sodat wie hom ookal aan die mag teenoorrangskik, $(a n t i=$ teen + tasso) staan teenoor (dit wil sê buitekant, weer anti) die dwarsdeurrangskikking (diatage, dit wil sê dia dwarsdeur iets heen + tage, selfstandige naamwoordsvorm van tasso) van God." Dit is duidelik dat Paulus hier voor sy geestesoog die beeld van die groot kosmiese rangskikking van "magte" sien. Die mense, en wel in allereerste instansie die gelowiges, die kerk, rangskik hulle onder die owerheid in, skik hulle dus na die owerheid; en wel om die eenvoudige rede dat die owerheid weer op sy beurt onder God in gerangskik is. Dit kán die gelowiges, die kerk, met soveel méér geesdrif doen, dit wil sê allermins teësinnig en halfhartig, omdat die kerk die enigste instansie ter wêreld is wat van hierdie rangskikking kennis dra. „Buite die kerk is daar geen plek in die wêreld waar 'n fundamentele kennis van die bestaansreg en die noodwendigheid van die staat $(=$ die owerheid) bestaan en uitgespreek word nie. Van alle ander kante af kan die staat ( = die owerheid), en kan elke afsonderlike staat (owerheid) met sy bemoeienis om menslike reg fundamenteel geproblematiseer word. Van die kant van die kerk met sy verkondiging van die Goddelike reg- 
verdiging aan alle mense, kan dit nie gebeur nie. Want vir die kerk is die staats-(owerheids-)gesag ingeslote in die gesag van sy Heer, Jesus Christus." ${ }^{13}$ ) Die kerk is immers die enigste instansie ter wêreld wat wéét dat daar 'n onverbreekbare ,kosmiese" rangskikking van magte bestaan, en wat die troosryke kennis dra dat daardie rangskikking só lyk: „Bo alle owerheid en mag en krag en heerskappy sit daar Christus”, (Ef. 1:21), ,,aan wie gegee is alle mag in hemel en op aarde", (Mat. 28:18), wat ook ,as Hoof bo alle dinge aan die gemeente gegee is" (Ef. 1:22). Onder Hom ín gerangskik bevind die owerhede en magte hulle, vir die gelowiges, die kerk, éénmaal onherroeplik ,uitgeklee en in die openbaar ten toon gestel en oor hulle getriomfeer" (Kol. 2:15). En dan ,elke mens", maar in allereerste instansie séker die gelowiges, die kerk, - en juis omdat hulle dit alles wéét, vreesloos, blymoedig, geesdriftig onder die owerhede en magte in gerangskik, ,skape tussen die wolwe", "soos suurdeeg wat uiteindelik die hele deeg suur maak ..."

Om hom enige plek ter wêreld te skik na die owerheid, óf na welke staatkundige of maatskaplike reëling ook omdat dit vir die heil van die mense wenslik is in swang mag wees, daarvoor besit die kerk 'n weergalose soepelheid. „Alles behoort (immers) aan julle ..." (I Kor. 3:22). Daar is GEEN enkele staatkundige of maatskaplike reëling, op voorwaarde dat hy ,goeie politiek" verteenwoordig, waarná die kerk hom nie kan en moet skik nie, waarin die kerk nie kan en moet ingaan, om daarbinne-in, daar-onder-in-gerangskik, ,solıt van die aarde" te wees nie. Dáárom is daar geen dwaser strewe in die wêreld as dié wat die kerk oral en altyd eenders wil hê, in éen selfde ge-ykte patroon wil inpers nie. Dít hou die verloëning én die vernietiging in van die essensiële soepelheid en lenigheid van die geloof, die bodemlose vindingrykheid van die Heilige Gees, die onstuitbare beweeglikheid van die kerk, die enigste manier hom gegee ter verowering van die wêreld vir Christus.

Die kerk eien dus vir homself geen uitsonderingsposisie hoegenaamd voor die landswet toe nie. „Op die politieke vragen kunnen ook Christenen alleen maar antwoorden in den vorm van beslissingen, die naar vorm en inhoud ook de beslissingen van andere burgers kunnen zijn, van welke zij ook moeten wensen, dat ze ook die van alle andere burgers mochten worden."14) Die kerk betaal sy skuld aan God deur, in sy prediking en die inrigting van sy lewe, die owerheid wat in 'n bepaalde staatkundige of maatskaplike situasie ,goeie politiek" beoefen, te gehoorsaam. Soos die gelowige burger is van die koninkryk van die hemele, nie net in die kerk nie, maar ook op kantoor, op die sportveld, op die dansbaan, en in sy eie huis, só is die burger van die koninkryk van die hemele ook as landsburger mede-verantwoordelik vir die ,goeie politiek" van sy land, nie net van Maandag tot Saterdag nie, maar ook op Sondag in die kerk. Wat die handhawing van wet en orde in belang van alle mense, en die beskerming van die reg en die vryheid van alle

13) Karl Barth, a.a.O., S. 39.

14) G. C. van Niftrik, a.w., bl. 303. 
mense, in die straat benadeel, benadeel dit ook in die kerk; en dit na dié mate waarin die balans tussen wet en orde enersyds en reg en vryheid andersyds, alreeds delikaat en sensitief mag wees.

Die kerk is óók 'n stuk staatkundige en maatskaplike lewe. Wat hy méér as dit is, is hy deur die geloof. Om inderdaad méér as dit te kán wees, daarvoor ontvang hy die geskenk van die Heilige Gees. Die realiteit daarvan hang vir hom nie af van wat hy daarvan te sien kry nie. Hoe sinneloos sou die kerk dán wees! En wat hy daarvan trag te gehoorsaam doen hy só, - - dit is die voorreg opgeslote in die geskenk van die vryheid van die kinders van God - dat dit die heil van die mense dien, en nie só dat dit hulle die lewensmoontlikheid ontneem nie. Wat in die straat verbode is, is ook in die kerk verbode. Die kerk is geen vry stad binne die staat waar oortreding van die landswet ophou om strafbaar te wees nie. Dit sou 'n doemwaardige dag wees wanneer die kerk dié plek moes word waar wat heilsaam is vir alle mense, ongestraf verontagsaam kan word, die een plek ter wêreld waar wat 'n bedreiging is vir die ,irdischen Staat als solchem"15) ongehinderd beoefen mag word - en dít dan in die naam van Christus! „The church has to oppose anarchy and all Zealotism within its own ranks." ${ }^{16}$ ) Die kerk moet die één plek in die land wees waar polisie-optrede nie nodig is om te verseker dat wat in belang van alle mense is, nagekom word nie. Die kerk moet die taak van die owerheid nie moeiliker mak nie, maar makliker.

Dit gaan hier om die grondliggende vraag na die verhouding tussen die van-buite-af-komende evangelie van Christus, en die op-'n-bepaaldetyd-en-plek-gangbare vorm van die samelewing $r$ an die mense. Is die evangelie revolusionêr, sodat dit bestaande bindinge en samehange plotseling vervang deur die nuwe lewe van die kinders van God, wat klaargemaak, volgens eenvormig-dwingende patroon, binne die vier mure van die kerk uit die hemel val? Of is hy anargisties, sodat hy net omvér werp, sonder om iets anders te voorsien? Of is hy eskatologiesdinamies, sodat hy in enige vorm van die samelewing van die mense op die aarde kan ingaan; homself kragtens sy eskatologies-voltooide waarheid en geldigheid, „saam met Christus verborge in God”, (Kol. 3:3) in enige vorm wat as heilsaam vir die mense in swang is, kan handhaaf; op enige sodanige vorm beslag kan lê, om dit, juis só geheiligd, aan te wend in die diens van Hom wat sê: „,Kyk, Ek maak alles nuut” (Openb. 21:5); dit van binne uit deur die krag van die geloof dinamies kan omvorm en bly omvorm - want wanneer kom dit klaar? - na die gestalte van die ware God-gegewe medemenslikheid wat by óns sigbaar sal word eers op die dag "wanneer ons Hom sal sien soos Hy is" (I Joh. 3:2); en deur dit alles heen hierdie God-gegewe geskenk deur die geloof eskatologiesreëel -- maar dan ook ALLEEN eskatologies-reëel, deur die geloof, en op geen ander wyse nie - van die eerste tot die laaste oomblik in sy ryke volheid én in sy volle rykdom kan besit?

15) Karl Barth, a.a.O., S. 41.

18) O. Cullmann, l.c., p. 90. 
Cullmann ${ }^{17}$ ) beantwoord hierdie vrae heel duidelik: „The church will fulfil its assignment if it remains faithful to the fundamental eschatological attitude of the New Testament. It could be shown how in the course of history the church has always assumed a false attitude toward the state when it has forgotten that the present time is already fulfilment but not yet consummation."

Omdat die evangelie voor alles eskatologies is, daarom kan dieselfde Paulus konstateer van ,die nuwe mens waar daar nie slaaf of vry man is nie”, (Kol. 3:11) maar tog ook eis: „Slawe, wees gehoorsaam aan julle here na die vlees" (Ef. 6:5). Dié twee uitsprake sluit mekaar nie uit nie, maar in. Juis die versekering van die eerste mak die uitvoering van die tweede moontlik. Die versekering van die eerste fundeer die vryheid van die kinders van God, waarin alle dinge moontlik is vir die een wat glo, waarin dit ook moontlik is ,,vir elkeen om voor God te bly in die staat waarin hy geroep is" (I Kor. 7:24). Dat slawerny opgehef is, is eskatologies-waar, en daaraan kan nooit weer verander word nie; dáárom kan die slaaf slaaf bly, sonder om daardeur skade te ly. „In al hierdie dinge is ons méér as oorwinnaars..." (Rom. 8:37).

Presies dieselfde geld van die eskatologiese gelykwaardigheid van man en vrou voor God in Christus, en die skerpe teregwysing aan die vroue om hulle te hou aan die maatskaplik-geldende norme van wat betaamlik is.

En omdat die evangelie dinamies is, ,'n krag van God" (Rom. 1:10), daarom sorg hy wel vir die afskaffing van slawerny op die aarde, egter nie rewolusionêr-anargisties, dit wil sê voetstoots op elke plek waar Paulus die evangelie verkondig, sodat Paulus met reg as 'n agitator en oproermaker beskuldig sou kon word nie, maar geleidelik, na 18 eeue Christendom, op die wyse van die suurdeeg wat uiteindelik die hele deeg suur maak. So stuur Paulus Onésimus na Filémon terug en laat dit aan hulle gemeenskaplike geloof oor om as slaaf en heer dié samelewingsvorm te vind en te skep wat ordelik sal wees. „Die wind waai waar hy wil, en jy hoor sy geluid, maar jy weet nie vanwaar hy kom en waarheen hy gaan nie." En hierdie gang van sake ten opsigte van die slawerny beteken nie dat die uitspraak van Kol. 3:11 vir die vrygemaakte slaaf van 1824 , één blou duit waarder was as vir Onésimus nie!

Presies dieselfde geld van die emansipasie van die vrou.

Sou iemand werklik durf beweer dat die geloofseenheid tussen slaaf en vry man in die slawernylose twintigste eeu met sy gapende kloof tussen werkgewers en werknemers vir die kerk minder problematies is as in die dae van Filémon en Onésimus? Of dat die geloofseenheid tussen man en vrou, in die huwelik én in die gemeenskap, in die twintigste eeu met sy ge-emansipeerde, selfstandige vrou, beter verwesenlik word as in die geval van Aquila en sy wetlik-onderhorige vrou, Priscilla? Die eskatologiese waarheid van die evangelie word deur staatkundige

17) O. Cullmann, l.c., p. 90. 
wetgewing of deur maatskaplike reëlings nie meer of minder waar gemaak nie. Daarom eerbiedig die kerk dit, ,,skik hy hom daarná”, en gebruik hy die "rustige en stil lewe" wat daardeur in stand gehou word, dit wil sê hy probeer dié nie-verongeluk nie - om die evangelie te verkondig, ,want dit is goed en aangenaam voor God, ons Verlosser, wat wil hê dat alle mense gered word en tot kennis van die waarheid kom." Siedaar die soepelheid van die kerk!

Ook in sy kerklike praktyk skik die kerk hom na die goeie politiek van die owerheid. Dit is die werklike betekenis in hierdie diskussie van die slaaf/vry-man en man/vrou uitsprake van Paulus. In die wêreld van Paulus het die vermenging van slawe en vry manne of van mans en vrouens geen bedreiging vir wet en orde ingehou nie. Daarom was dit nie verbied nie! Wat wel 'n bedreiging vir wet en orde sou inhou, sou die misbruik wees van die eskatologiese waarheid van die kerk, naamlik dié van die vryheid van slawe en die gelykwaardigheid van vroue in Christus, om die maatskaplike orde binne óf buite die kerk op te hef. En dit verbied Paulus uitdruklik vir slawe sowel as vroue! Uit sy opdrag tot voorbidding vir ,'n rustige en stil lewe" mag seker afgelei word verderaan sal die goeie reg van so 'n ,afleiding" verdedig word - dat, as die owerheid dit nodig geag het om ter wille van wet en orde die saamverkeer van slawe en vry manne óf van mans en vrouens te verbied, en Paulus geoordeel het dat so 'n stap ter wille van die rustige en stil lewe waarvoor die kerk bid, werklik nodig was, dat so 'n stap met ander woorde ,goeie politiek" verteenwoordig het, hy hom aan so 'n reëling sou onderwerp, en die gemeentes sou oproep om dit saam met hom te doen. En dan sou die elfde vers van hoofstuk 3 nóg, net so onverswak, daar in die Kolossensebrief gestaan het!

In Hand. 19:28 volgende staan inderdaad die geskiedenis vermeld van 'n dag waarop Paulus, mede op aandrang van sy ,dissipels" (vs. 30) en "owerstes van Asië wat sy vriende was", (vs. 31), afgesien het van sy voorneme om ,onder die volk in te gaan” (vs. 30), en geen protes aangeteken het nie toe "die stadsklerk" (vs. 35) die vergadering wat hy wou toespreek, sonder meer „ontbind” (vs. 40), „omdat ons gevaar loop om oor die oproer van vandag aangeklaag te word". Hy laat hom deur die stadsklerk die vryheid en die geleentheid om te preek ontneem ter wille van die herstel van wet en orde. Wie hierdie geskiedenis lees, kan nie anders as om te dink aan sekere periodieke byeenkomste op die trappies van 'n bepaalde stadsaal in Suid-Afrika nie. Paulus maak geen aanspraak op 'n aangematigde reg of ' $n$ vermeende vryheid om in naam van die verkondiging van die evangelie oproerigheid te veroorsaak of te vermeerder of die beëindiging daarvan te verhinder nie.

Wat die kerk voor God an die owerheid verskuldig is, is die voortdurende oproef tot die beoefening van ,goeie politiek", dit wil sê politiek wat sal meewerk tot die behoud van 'n ,,stil en rustige lewe in alle godsvrug en waardigheid"; die verantwoordelike afweeg van goed en sleg in die politiek: die vreeslose keuse, in die vorm van 'n geloofsbeslissing, vír 
wat in 'n bepaalde situasie goeie politiek sal wees; profetiese kritiek nie oproerige rugstekery nie - téén wat volgens hierdie geloofsbeslissing slegte politiek sal wees; en onwrikbare lojaliteit langs die hele linie van die lewe van die mense - tot in die inrigting van die lewe van die kerk toe - teenoor die goeie politiek van die owerheid.

Wat an die keiser gegee moet word omdat dit die keiser toekom, mak inherente deel uit van wat aan God gegee moet word omdat dit God toekom.

\section{Die Owerheid en die Rassevraagstuk in Suid-Afrika}

„Rassevraagstuk” beteken die soek na die beste samelewingsmetode vir mense van verskillende ras of kleur in bepaalde getalsverhoudinge. In die sin van hierdie definisie het baie lande 'n rassevraagstuk. Die dringendheid en grimmigheid van die vraagstuk hou egter verband met die getalsverhoudinge. Daarom geniet die rassevraagstuk in Brittanje of Wes-Duitsland weinig prominensie in die politieke programme van hierdie lande. En die dringendheid en grimmigheid van die vraagstuk hou ook verband met die kultuur- en beskawingsverskille wat daar bestaan. Daarom kan die binnelandse rassevraagstuk van die V.S.A. onder die groot politieke strydvrae van daardie land grootliks agterweë bly. In al drie hierdie lande het 'n oorweldigend-grote Blanke meerderheid met 'n nietige nie-Blanke minderheid te doen. Die breë politieke, maatskaplike en kulturele lewe van die land en volk kan in geen noemenswaardige mate deur die vorm van die verkeer tussen die rasse beînvloed word nie. En in die V.S.A. is die kultuur- en beskawingsverskille wat daar tussen die rasse was, daarboonop ook nog nagenoeg uitgewis. Daar kan dus in hierdie lande, en veral in die V.S.A., deur welke benadering van die rassevraagstuk ookal gehuldig word, weinig in gevaar gebring word. 'n Harmoniese samelewing kan van die kant die Blankes hoogstens deur kleurbewussyn en van die kant van die nie-Blankes hoogstens deur doodgewone onbillike eise of misdadige optrede versteur word. Die rassevraagstuk, vir sover leidende Westerse volkere met hom te doen het en van hom kennis dra, is ' $n$ doodgewone en daarby minder-belangrike binnelandse aangeleentheid, van nóg minder deurslaggewende betekenis in die bepaling van die politiek van hierdie lande, as byvoorbeeld die verhouding tussen werkgewer en werknemers in 'n bepaalde bedryf.

Presies dieselfde geld in omgekeerde rigting van haas elke gebied in Afrika. Behalwe Suid-Afrika, is die uitsonderings, Algerië, die Federasie van die Rhodesiës en Niassaland, en Kenia, hoogstens grensgevalle. Hier bestaan prakties-homogene bevolkings. En ,rassevraagstuk" beteken hier dus nie veel meer as die soek na die beste metode van oordrag van die beheer van hierdie gebiede deur Blanke moondhede aan die inheemse bevolkings self nie.

Die rassesituasie in Suid-Afrika is sonder parallel in die wêreld. Hier woon drie miljoen Blankes te midde van nagenoeg drie maal soveel nie-Blankes. En tussen hierdie twee groepe is die kultuur-en bekawings- 
verskil, wat 99 persent van die lede van elk van die groepe aanbetref, op sy allerkleinste so groot as wat die verskil as staatsmanne is tussen Harold MacMillan en Patrice Lumumba. Dít was ook die geval met die verskil tussen Blankes en nie-Blankes in Ghana en ander Afrikagebiede. Wat in Suid-Afrika anders is as waar ook anders, is dat hierdie drie miljoen Blankes opgehou het om die aanhangsel te wees van enige ander moondheid ter wêreld. Hier is 'n afsonderlike volk met 'n eie wordingsgeskiedenis agter hom, met 'n eie gestalte van die Westerse beskawing en kultuur wat uit hierdie grond gegroei het en in hierdie grond veranker is, met eie toekomsaspirasies en ideale, en met geen ander tuiste ter wêreld nie. Wie dus in Suid-Afrika vir die rassevraagstuk dié oplossing eis wat in ander Afrikagebiede vermeend geslaagd was of in eksperimentele stadium is, en wat daarop neerkom dat die vraagstuk opgelos word deur hom af te skaf, met ander woorde deur die aanwesigheid van die Blankes te beëindig, die eis nie alleen die redusering van die kultuur- en beskawingspeil van hierdie land tot dié wat die volkere van Wes-Europe teen die einde van die eerste eeu N.C. besit het nie, maar dié eis as betaling vir die verwesenliking van hierdie reduksie daarbóónop ook nog die prys van die vermoording van 'n volk wie se rekord, wat sy omgang met ander volkere aangaan, onder die Westerse nasies seldsaam skoon is. Sekerlik sal dit wesenlik tot die taak van die kerk teenoor die owerheid van hierdie volk behoort om met aandrang te getuig dat die beskerming van die reg en vryheid van alle mense in hierdie land die vrywaring van hierdie volk teen hierdie moontlikheid insluit!

In Suid-Afrika beteken ,rassevraagstuk" die soek na 'n samelewingspatroon vir Blank en nie-Blank wat die voortbestaan van wet en orde sal verseker op so ' $n$ wyse dat doeltreffende beveiliging verleen is aan die reg en vryheid van die Blankes om te geniet van - en uit te bou aan dié unieke gestalte van die meer as 20 eeue-oue Christelike Westerse kultuur en beskawing wat in die afgelope drie eeue op Afrikaanse grond oorgeplant en uit Afrikaanse grond nuut geörienteer en gestimuleer is; om hierdie kultuur en beskawing deur te gee in die hande van 'n nageslag wat so ' $n$ kosbare en bedreigde besit sal kan behou; en sodoende aan die 200,000,000 nie-Blankes van Afrika dié bydrae tot die vorming van die toekoms van Afrika te lewer wat niemand anders kán lewer nie; maar tegelyk op so ' $n$ wyse dat ook beveiliging verleen is aan die driedubbelgetalsterke nie-Blankes (met hulle kulturele en beskawingsagterstand van 1860 jaar, en hulle gevolglike onvermoë om óór die gaping van 1860 jaar beskawingsgeskiedenis heen, waarvan hulle slegs baie oppervlakkig van hoorsê kennis dra, verantwoordelike trustees te wees van die enigste kultuur- en beskawingsgestalte in Afrika wat met dié in die res van die wêreld vergelykbaar is, se reg en vryheid tot volle ongehinderde selfverwesenliking, dáárin ook in die toekoms bestendiglik en onontbeerlik gedien deur die stimulus van 'n behoue en ongeskonde en lewenskragtige en bloeiende gestalte van die Westerse beskawing in hulle midde, dieselfde stimulus wat by hulle die begeerte self tot selfverwesenliking wakker 
geroep het. Die ontwakende en verwoede selfbeskikkingsdrang van die nie-Blanke, in Suid-Afrika vanweë die langere aanraking met die Westerse kultuur inderdaad sterker as elders in Afrika, en daarboonop onberekenbaar voortgestu deur die wyse waarop die vraagstuk elders in Afrika "opgelos" word, dit wil sê deur hom af te skaf, met ander woorde deur die anwesigheid van die Blanke kultuur- en beskawingsdraer nie te beveilig nie maar te beëindig, maak van die rassevraagstuk in Suid-Afrika dié alles-oorheersende sektor van sy staatkundige besigheid. By die hantering van die rassevraagstuk in Suid-Afrika gaan die om die bedreigde behoud van 'n ordelike staatkundige lewe self! Sal die wêreld, ná die gebeure van 1960 in die Belgiese Kongo, aanvaar dat dit in Suid-Afrika om die behoud van die lewe self gaan? En dít, die behoud van die lewe self, sou ook nie so 'n belangrike oorweging gewees het as dit nie so 'n onmiskenbare feit was dat die verdwyning van die Blankes in SuidAfrika sinoniem is met die verdwyning van die cnigste beskawingsvesting in Afrika wat op vaste fondament staan nie. Die kerk wéét dat dit ook sinoniem is met die verdwyning van die enigste bruggehoof van die Christelike geloof in die Suide van Afrika. En dít kan nóóit ,goed en aangenaam (wees) voor God, ons Verlosser", nie! Moet die meer as 'n eeu van sending in Afrika sy klimaks vind in die uitspraak: „Laat die Here self, met behulp van die wankelende inheemse kerkies, oorgelaat aan die genade (genade!) van die Nkrumah's en Lumumba's en Nassers en Kroesjtjefs verder daarvoor sorg?" Moet dít in die twintigste eeu dié getuienis van Jesus Christus wees wat die kerk gebode is? Jesus Christus eis seer seker martelaarskap van die kerk. Maar martelaarskap is nie sinoniem met selfmoord nie! Martelaarskap getuig van geloof. Selfmoord getuig, sedert Judas Iskariot, hoogstens van gepleegde verraad!

Nou het daar gedurende drie eeue van saam-verkeer in Suid-Afrika geleidelik 'n samelewingspatroon vir Blank en nie-Blank ontstaan. Die rol van die kerk in die bestendiging van hierdie patroon is reeds vermeld, en is bekend. In die beginjare van die Blanke nedersetting aan die Kaap was hierdie patroon nog nie daar nie. Hy is nie van elders af hierheen gebring nie. Hy het hier ontstaan. Hierdie samelewingspatroon het later, toe hy diskussie moes ondergaan, verskillende name gekry: segregasie, apartheid, eiesoortige ontwikkeling.

Die opvallende feit is dat die beginsel van rasseskeiding waarop hierdie patroon berus, homself oral in Afrika waar Blank en nie-Blank saam moes verkeer, gemanifesteer het. In elke Afrikagebied is daar 'n gedragslyn vir die noodwendige punte van aanraking tussen Blank en nie-Blank gevind, maar is, hier strenger, daar rekbaarder, die beginsel van rasseskeiding op ander lewensterreine neergelê. Alleen só was dit vir Blank en nie-Blank moontlik om met 'n minimum van wrywing in wet en orde saam te lewe sonder om mekaar se regte en vryhede aan bande te lê.

Hierin het ná die tweede wêreldoorlog drastiese verandering gekom. Die voortgaande-industrialisasie van die inboorling, sy aanraking met die 
Westerse leefwyse, en veral sy deelname aan die keslissing van die uitslag van die wêreldoorlog, afgesien van die aanblasing en aanhitsing uit verskillende rigtings van die groot politiek van die wểreld, het by halfontwikkelde elemente van die inheemse bevolkings die drang tot selfbeskikking, wat die afwerping van die koloniale juk beteken, laat ontstaan. Vir die koloniserende moondhede het dit mede as gevolg van die wêreldsituasie, ${ }^{18}$ ) spoedig duidelik geword dat, ook ter wille van die behoud van 'n invloedsfeer, lewensbelangrike handelsmoontlikhede, én internasionale prestige, die bewind in die koloniale gebiede so vinnig moontlik moes oorgaan in die hande van die inheemse bevolkings. Bó alles moes hierdie oorgang, omrede van dieselfde oorwegings, so ordelik moontlik plaasvind, dit wil sê met 'n absolute minimum aan spronge en skokke.

Toe is gedurende dieselfde jare in die hoofstede van die koloniserende moondhede, London, Parys, Brussel, 'n patroon gevind wat die antwoord moes bied op die vorm wat die rassevraagstuk op daardie stadium vir dié bepaalde owerhede aangeneem het. Hierdie patroon is in wesenstrekke dieselfde, en kom neer op die vinnige opname van die nie-Blanke in al die lewensterreine van die Blanke, met die oog op die uiteindelike vervanging van die Blanke deur die nie-Blanke in al die verantwoordelike posisies van die samelewing, dit wil sê op politieke, maatskaplike en ekonomiese terrein. „Rassevraagstuk” het hier nou dringend en grimmig beteken die soek na 'n metode om die oorgangstadium tussen Blanke bewindvoering en volledige onttrekking van die Blanke te oorbrug. 'n Metode moes gevind word ,to facilitate withdrawal of the whites with as little loss of influence or prestige as possible." En die antwoord wat op hierdie vraag gevind is, het in al hierdie gevalle gelui: integrasie van Blank en nie-Blank. Dat hy telkens 'n ander naam gedra het: die ontwikkeling van 'n klas „Belgische Afrikanen" ${ }^{19}$ ) in die Belgiese Kongo, die "multiracial experiment" in Brits-Oos-Afrika, ,racial partnership" in die Sentraal-Afrikaanse Federasie, ens., verander nie daaraan dat dit wesentlik dieselfde antwoord is nie.

Dat hierdie antwoord die doel waarvoor hy uitgedink is, dien goed óf sleg-, kan nie betwyfel word nie. Dat hy die „withdrawal of the whites" uitmuntend dien, en onmiskenbaar verhaas, is baie duidelik. In 1955 nog kon 'n ene mnr. Basil Davidson ${ }^{20}$ ) die volgende woorde in die mond van 'n Belgiese (kapitalistiese?) „prins" lê: „In my opinion we shall have to rely on the blacks for pretty well everything, and hope that they won't kick us out in fifty years' time - or sooner. If we treat them right, they won't." $O$, sancta simplicitas! Hoe dit egter met die "as little loss of influence or prestige" gesteld is, val te besien. Die diens wat die integrasie-antwoord tot dusver gelewer het, kán so ge-interpreteer

18) Dis 'n sinnelose, maar nietemin interessante vraag: Wat sou die Westerse Lande se standpunt ten opsigte van die beëindiging van kolonialisme gewees het as hulle minder met Rusland rekening hoef te gehou het?

19) Koning Boudewijn in 'n radiorede uit Leopoldstad waarna die skrywer hiervan êrens tussen 1954 en 1957 in Brits Oos-Afrika geluister het.

20) Basil Davidson, The African Awakening, London 1955, p. 115. 
word dat die enigste party wat konsekwent aan die gunstige kant van die „loss of influence or prestige” bly, die Kommunisme is.

Dat die koloniserende moondhede, om ekonomiese, en magspolitieke redes bereid is om enige prys, tot die ,withdrawal of the whites" toe, vir die ,as little loss of influence or prestige as possible" te betaal, is begryplik. Dit gaan een en almal van hulle hierin immers om selfbehoud. Die bedoeling met die kolonisasie was om ekonomiese uitlate te bekom, en die bedoeling met die onttrekking van die Blankes is om daardie ekonomiese uitlate te behou. Dit gaan om ponde, sjielings en pennies! En of die bevolking van die gebied waar die eie ekonomie sy uitlaat vind, die mense wat die ponde, sjielings en pennies voorsien, wit of swart is, is geen oorweging hoegenaamd nie. Dáárom kan dieselfde Davidson onmiddellik na die aanhaling van so pas, voortgaan: ,This is the sort of long-range (sic!) calculation which the small local investor and employer never makes, and perhaps can not make: typically, in South Africa and Southern Rhodesia, as in the Congo, he sees the future only in terms of permanent white-supremacy on the spot. The big investor, on the contrary, can allow himself to make many concessions so long as the inviolability of exported profit remains assured." Die „long-range calculations" van die ekonomie gee die deurslag! En wie sal durf ontken dat al die mooi-klinkende slagspreuke van , distributing the boons of civilisation", ,bringing the British way of life", en wat dies meer sy, nie die byklank dra nie maar - self byklank is, van hierdie selfde „longrange calculation" van die ekonomie van die tuisland?

Wat egter nie begryplik is nie, is dat hierdie antwoord — van heinde en ver, van Ooste en Weste - vir Suid-Afrika as antwoord op sy rassevraagstuk aan die hand gedoen word, en op Suid-Afrika afgeforseer word, en in Suid-Afrika se keel afgedruk word. Hy ís geen alternatief vir die samelewingspatroon wat Suid-Afrika as antwoord op sy rassevraagstuk histories ontwikkel het nie. Hy was juis bedoel om die teendeel van wat in Suid-Afrika nagestreef word, te verwesenlik. Hy is bedoel om die beëindiging van die aanwesigheid van die Blankes te vergemaklik. Maar in Suid-Afrika gaan dit nou juis om die vind van 'n PERMANENTE samelewingspatroon vir Blank en nie-Blank! In Suid-Afrika is die één ding op die spel wat waaragtig méér gewig dra as ponde, sjielings en pennies óf as ,,as little loss of influence or prestige as possible”, naamlik die lewe self. En dít geld van die Blankes, sowel as dié nie-Blankes wat reeds ervaar het wat ,lewe", na die maatstawwe van die beskawing, beteken.

In Suid-Afrika ís daar vir die owerheid tot op datum nog nie 'n samelewingspatroon aan die hand gedoen wat, as antwoord op die RASSEVRAAGSTUK IN SUID-AFRIKA, in aanmerking kán kom nie. Hoogstens is aan die hand gedoen dat die owerheid sy oë vir die bestaan óf vir die unieke karakter van die vraagstuk sal sluit, sy wetgewing sal beëindig, en „die Here vir die toekoms sal laat sorg." Dit mag vreeslik gelowig klink, maar in Suid-Afrika beteken hierdie eis ,'n fundamentele 
,Nee' teenoor (die moontlikheid van) 'n aardse owerheid as sodanig, 'n houding wat onmoontlik Christelik kan wees", ${ }^{21}$ ) en dít met veel meer beslistheid as dié waarmee Karl Barth hierdie woorde in 1948 in die politieke situasie in Switserland uitgespreek het, omdat nóu híér die bedreiging van chaos en anargie veel minder denkbeeldig is as tóé dáár.

Daarom het die owerheid in Suid-Afrika die één weg bewandel wat ter behoud van wet en orde, gepaard met die verwesenliking van die hoogsmoontlike mate van reg en vryheid vir alle mense in Suid-Afrika wat ook deur die kerk van hom geëis is, en geëis word -, vir hom oop was. Hy het onderneem om die tradisionele en beproefde samelewingspatroon vir Blank en nie-Blank in Suid-Afrika vir die toekoms te bestendig, op so 'n wyse dat dit volle ruimte bied vir voldoening aan die eise van die veranderde omstandighede.

Dít hou hoofsaaklik twee dinge in: Ten eerste: Die geleidelike oorgang van die beheer in die nie-Blanke gebiede, uit die hande van die Blankes in dié van die inheemse bevolking self, presies soos in ander Afrika-gebiede met die volgende belangrike verskilpunte egter:

(a) Daar sal geen toegewing wees aan die gesindheid weerspieël in die berugte Nkrumah-slagspreuk: "Soek eers die politieke koninkryk en al die ander dinge sal vir julle bygevoeg word," nie. In plaas daarvan sal daar voorsiening gemaak word vir alle denkbare geleentheid aan die nie-Blanke se drang tot self beskikking, die sogenaamde ontwakende nie-Blanke nasionalisme, om langs opvoedkundige, maatskaplike, en ekonomiese kanale, daadwerklik mede-diensbaar te wees vir die opbou van 'n betroubare beskawingsfondament in die betrokke gebiede, waarop politieke onafhanklikheid heg en seker sal kan rus. Wié sal anders, ná politieke onafhanklik-wording ,,al die ander dinge byvoeg"? Die V.V.O.? Soos in die Kongo? Of die Blankes in S.A.? En as dié daar nie meer is nie? Soos in die Kongo? Verantwoordelikheid, en die aanvaarding van verantwoordelikheid vir die toekoms van eie volk en vaderland, sal dus hier die toets wees vir die egtheid van 'n nasionalisme wat na selfverwesenliking dring.

Hieroor het Prof. H. Berkof in sy indringende studie „Christus de zin der geschiedenis", veral in die vyfde hoofstuk, besonder leersame konklusies geboekstaaf. Vernaamlik op bl. 90 en 91 spreek hy menings uit wat, onbewus, die goeie reg van die eis van verantwoordelikheid, soos in die vorige paragraaf omlyn, duidelik onderstreep. Hy bevind onder andere: ,dat de mensen die met de resultaten onzer cultuur in aanraking komen, (dit wil sê sonder om die grondslae van daardie kultuur te kon assimileer) erdoor worden ontworteld;" en verderaan: „De hooggeroemde hulp aan de onderontwikkelde gebieden wordt dan schijnbaar een materiële zegen, maar in werklijkheid een geestelijke aanranding." Wie in die verhouding tussen Blank en nie-Blank ge-

21) Karl Barth, a.a.O., S. 41. 
interesseerd is, kan alleen teen groot skade die inhoud van hierdie boek ignoreer.

(b) Hierdie ,antwoord" op die rassevraagstuk sal geen byklanke hê nie, en sal ook nie dien om enige ander belange te verbloem nie. Reg van die begin af word uitdruklik afstand gedoen van die ekonomiese voordeel wat in die toekoms uit die aldus-onafhanklik-geworde gebied te haal is. $£-s-d$ sal geen rol speel nie. Inteendeel die Blanke belastingbetalers van die „tuisland" dra by vér die grootste persentasie van die koste hieraan verbonde, en gee by verkiesing — ná verkiesing sy bereidwilligheid te kenne om dit ook in die toekoms te dra. Nog meer: die onafsienbare ekonomiese en ander moontlikhede van die nie-Blanke gebiede word uitdruklik vir nie-Blanke ondernemingsgees gereserveer. En die risikokapitaal vir sodanige nie-Blanke ondernemingsgees, word deur die Blanke tuisland voorsien. Selfs „loss of influence or prestige" sal geen oorweging wees nie. Méér as dit is hier op die spel. Daar is geen ruimte vir bybedoelings nie. Dit gaan om die behoud van die lewe self!

(c) Ook die onvervreembare reg en vryheid van die Blankes sal gewaarborg word.

Dis eerlike politiek hierdie. Snaaks genoeg is hierdie politiek as ,,anakronisties in die 20ste eeu" bestempel.

En ten tweede hou die bestendiging van die tradisionele samelewingspatroon in Suid-Afrika in: Die ferme be-eindiging van die integrasieproses wat, hand in hand met die industrialisasie van die nie-Blanke in die Blanke gebied, ook hier groot afmetings aangeneem het. Hier is die plek waar enkelinge en groepe as gevolg van hierdie beleid leed te verduur sal kry. Dit is egter ongelukkig so dat, as daar maar een samelewingspatroon is wat die heil van alle mense sal dien, sy bestendiging ook die bekamping sal beteken van die proses wat hom roekeloos ondermyn. Die owerheid kan beswaarlik eiesoortige ontwikkeling nastreef, en terselfdertyd integrasie ongehinderd laat voortwoeker. Hier kan alleen, maar móét ook onvoorwaardelik ge-eis word dat elke individuele geval met die allergrootste menslikheid en begrip gehanteer sal word, dat niks weggeneem sal word sonder om vergoed te word nie, en dat die toemaak van enige deur êrens die heenwysing sal insluit na 'n reedsgeopende deur elders.

Die owerheid in Suid-Afrika het 'n geregverdigde aanspraak op begrip in die wêreld, vir die unieke karakter van die rassevraagstuk in Suid-Afrika, sowel as vir die onloënbare feit dat, vir die be-antwoording van 'n unieke vraagstuk, alleen 'n unieke antwoord in aanmerking kan kom.

\section{Die Kerk en die Rassevraagstuk in Suid-Afrika}

Die kerk vra in al sy doen en handel na die wil van God. Dié verneem hy in die Bybel.

Die Bybel is nie téén eiesoortige ontwikkeling nie! En die Bybel 
is nie vir eiesoortige ontwikkeling nie! Ongelukkig bestaan daar hieroor weinig helderheid, met die gevolg dat die kerklike diskussie in dié verband nog maar baie weinig bokant die absoluut-onteologiese vlak uitgestyg het van die emosionele uitroep: „die Bybel eis apartheid!" óf: „,die Bybel verbied apartheid!" Dat elkeen van hierdie uitroepe met 'n klomp tekste ,gestaaf" word, verander nie daaraan dat dit 'n dwaling verteenwoordig nie, die een so erg as die ander. Dit bly 'n ,gryp na die Bybel om eie standpunt te staaf."

Die eenvoudige en tog aksiomatiese waarheid is dat die Bybel die situasie in Suid-Afrika nie ken nie. Langs die hele eeuelange linie van die Bybelse geskiedenis kom daar nie 'n enkele situasie voor wat met die rassesituasie in Suid-Afrika in die twintigste eeu, selfs by benadering vergelykbaar is nie. Daarom kan geen enkele Bybelwoord op die situasie in Suid-Afrika „onge-exegetiseerd" van toepassing gemaak word nie. Exegese, die hele teologiese wetenskap, die prediking van die kerk, is juis niks anders as om die eenmaal-in-'n-konkrete-historiese-situasiegesproke Woord los te maak uit die tyd-ruimtelike windsels van die verbygegane situasie, en dan daardie Woord opnuut lewende werklikheid te maak in die huidige situasie nie.

Die Here spreek nie ,,in die lug" nie. Die Here praat met mense wat op 'n bepaalde dag op 'n bepaalde plek onder bepaalde omstandighede voor 'n bepaalde keuse staan. En elke kombinasie, van plek, tyd, omstandighede en keuse is eenmalig en onherhaalbaar. Die teologie werk nie soos die regswetenskap met ,presedente” nie. Daarom kom die teologie nooit klaar nie. Om teologie te beoefen, is iets gans anders as om uitsprake te kodifiseer.

Dat Moses 'n Kusietiese vrou geneem het, en wat diê se huidskleur was, sê in die rassesituasie in Suid-Afrika net mooi niks! As sy nieBlank was, wat bewys dit? Klaarblyklik doodeenvoudig en alléén dat Moses geen beswaar gehad het om met 'n nie-Blanke te trou nie. Waarom sou hy ook beswaar daarteen hê? Wat kon daardeur in gevaar gebring word? Nog minder as wat in die jaar 1960 in Ghana of in Duitsland in gevaar gebring word deur die ge-isoleerde geval van die huwelik tussen 'n Blanke en 'n nie-Blanke. Om daarteen beswaar te hê, soos Aäron en Miriam in die geval van Moses gehad het, en soos vele Blankes in Duitsland en vele nie-Blankes in Ghana in die gevalle wat dáár voorkom, sekerlik het, kan alleen uit kleurvooroordeel spruit. En dié moet dan as sodanig be-oordeel word. Maar dan nóg sal elkeen van hierdie drie gevalle 'n splinternuwe situasie verteenwoordig, waar grondig, biddend, na die wil van die Here gevra sal moet word. So min as wat die teregwysing van die Here aan Aäron en Miriam gebruik kan word om te bewys dat, die wet wat veelwywery verbied, uit die bose is, netso min mag dit misbruik word om aan te toon dat die verkeer tussen Blankes en nie-Blankes ipso facto bo kontrole deur die owerheid verhewe is. Hoeveel minder mag hierdie Bybelwoord dan in die diskussie oor die rassevraagstuk in Suid-Afrika ingesleep word! Gans ander dinge is hier op die spel. Dit 
gaan hier inderdaad by die reëling van die verkeer tussen Blank en nie-

I Blank om die heil van alle mense. Die kerk dien niemand deur die oë hiervoor te sluit nie.

Dieselfde moet ook gesê word van die ander Bybelfigure wat steeds weer een of ander tyd in hierdie diskussie hulle verskyning maak: Simon van Cirene en die kamerling van Etiopië. Betreklik onlangs is selfs die stomme Augustinus deur 'n Nuwe Testamentikus, amptelik-getrou aan die gees van die dag, tot die bevoorregte status van nie-Blanke verhef. ${ }^{22}$ )

( $E k^{*}$ vind dit ' $n$ klein bietjie bevreemdend dat dieselfde persone wat heilig-verontwaardigd protesteer teen die ,klassifikasie” van mense in Suid-Afrika as nie-Blankes, asof die 'n onvergeeflike vernedering inhou, tog geen oomblik huiwer nie, nee, inteendeel, hygend-gretig is, om historiese figure wat die agting en dankbaarheid van 'n ganse mensdom verdien en geniet, as nie-Blankes te „klassifiseer" - en dit met veel minder bewysgrond as waarmee die bevolkings-klassitikasie van owerheidsweë in Suid-Afrika plaasvind. Vir hierdie geleerdes is blote geogratiese herkoms of woonplek immers aanduiding genoeg van iemand se huidskleur.)

Die regte verstaan van die bedoeling van die Bybel met die oog op die rassevraagstuk in Suid-Afrika en die standpunt van die kerk daarteenoor, sal nie die resultaat wees van die soek na 'n parallelle situasie nie, want die bestaan daar nie, maar wel alleen van 'n nugtere, in-die-taalvan-alledaagse-,,goeie-politiek"-vertaalbare begrip van die sentrale gebod van die Bybelse verkondiging. En dié haat nie koininia, gemeenskap, nie, maar agape, liefde. En juis hierdie agape kan nou onmiskenbaar ook die vorm aanneem van opheffing van die sigbare, vleeslike koinonia ter wille van die behoud van die veel hegter en blywender koinonia deur die Gees in die geloof. Daarvan spreek Joh. 16:7: „Maar Ek sê julle die waarheid: Dit is vir julle voordelig dat $\mathrm{Ek}$ weggaan ..." Daarvan spreek Mat. 28:20: „Ek is met julle al die dae tot aan die voleinding van die wêreld...," en dit net voordat Hy vir goed ,voor hulle oë weggeneem" is, in die taal van Hand. 1. As die agape van God hierdie vorm kan aanneem, kan daar 'n dag kom wanneer ook die agape van die kerk hiervoor nie sal mag terugdiens nie. Die agape van die kerk is nie 'n ander liefde as die van God in Jesus Christus nie. Die kerk beskik nie oor 'n groter liefde as dié van God nie, maar mag ook nie die liefde van God vir 'n kleiner, mensliker, sigbaarder, tasbaarder, vleesliker een verruil nie.

Daarom is dit weinig verbasend dat reeds in Bybelse tyd, onder leiding van die apostels self, die liefde van die kerk hierdie selfde vorm aangeneem het. Daarvan spreek Hand. 16 en Gal. 2. Hieroor skryf Oscar Cullmann boeiend en, sonder dat hy dit weet, met die oog op die kerk en die rassevraagstuk in Suid-Afrika, besonder insiggewend . ${ }^{23}$ )

${ }^{22}$ ) A. S. Geyser, Christelike Godsdiens en Eiesoortige Volksdiens, artikel in Hervormde Teologiese Studies, Jaargang 1-, Pretoria 1960, bl. 15.

23) O. Cullmann, Petrus, Jïnger, Apostel, Martyrer, Zürich 1952, Hfstk. 2. 
Nie al die teoloë wat meedoen aan die diskussie oor hierdie onderwerp, met verswyging van hierdie betoog van Cullmann, kan van die strekking daarvan heeltemal onbewus wees nie. ,'n Beslissende kerksplitsing, vreedsaam soos dit was, het dus reeds in die oer-christendom plaasgevind," skryf hy letterlik. Volgens hierdie vreedsame kerksplitsing sou „ons na die heidene en hulle na die besnedenes gaan”. (Gal. 2:9). En let wel: juis hierdie uitmekaar-gaan van die weë beteken dat hulle aan ons „die regterhand van gemeenskap" (koinonia) gegee het. Dit gaan om die voortgang van die evangelie in die wêreld. Dié is vir die eerste sinode van die Christelike kerk, waarvan ons in Hand. 16 en Gal. 2 lees, maar ook vir die kerk in Suid-Afrika, belangriker as vleeslike, sigbare gemeenskap. Maar dáárvoor, só skryf dieselfde Paulus, is 'n ,,rustige en stil lewe" onontbeerlik. 'n „Liefde" by die kerk waarvoor ongekwalifiseerde gemeenskap die hoogste goed geword het, ook wanneer dit 'n bedreiging vir wet en orde is, is nie meer die liefde van dié God „wat wil hê dat alle mense gered word en tot kennis van die waarheid kom" nie. Dit het opgehou om agape te wees, het vleeslike liefde geword, eros.

Die hoogste openbaring by die kerk van die liefde van God in Jesus Christus, sal nie te vinde wees in die ,,saamsit met medegelowiges" nie, maar in 'n ,sy getuies wees in Jerusalem, sowel as in die hele Judea en Smatia en tot aan die uiterste van die aarde". In Suid-Afrika is 'n groot aantal Blanke kerke, maar-en dit moet vir enigiemand wat hierin geinteresseerd is, groot gewig dra-, ook reeds 'n aansienlike deel van die nie-Blanke kerke, nie sonder biddende verantwoording voor God nie, daar grondig van oortuig dat hierdie taak ook hiér, nie beter verrig kan word as by wyse van 'n reëling waarvolgens ,,ons na die heidene en hulle na die besnedenes kan gaan” nie, „langs die pad van afsonderlike volkskerke", heet dit nou hier in hierdie situasie.

Die koinonia van die kerk is ondergeskik an sy diakonia, dit wil sê sy diens in die wêreld. „Het gaat Paulus niet om een of ander emancipatieideaal, maar om Jesus Christus en zijn dienst. Daarom moet elke schijn vermeden worden van revolutionnair-idealisme of libertinisme. Aardsche idealen mogen niet verduisteren dat het gaat om Jezus Christus. Vandaar dat de gemeente beginnen moet zich te voegen naar (,,skik na" het óns hoër-op gesê) de bestaande burgelijke zede en het algemeen als oorbaar aanvaarde." 24) Wat in Suid-Afrika, ook met die oog op die rassevraagstuk, 'n saak van dodelike erns is, is die vraag: „Hoe verrig die kerk sy diens (diakonia) die beste in hierdie land", en nie die vraag: „Wie sit by wie in die kerk", nie. Belowende en knap teoloë het tussen hierdie twee vrae verward geraak, en sodoende kerk en evangelie 'n skone en kosbare diens skuldig gebly! Van geweldige belang is ${ }^{25}$ ) dat koinonia by Paulus in verreweg die meeste gevalle te make het met die finansiële bystand van die heidengemeentes aan die wat nie het nie. Koinonia

24) Het Gemeentelid, Rapport van die Interkerkelijke Commissie voor Leekenarbeid, Amsterdam 1946, bl. 21 .

${ }^{25}$ ) Dr. S. P. J. J. van Rensburg het in 'n rapport daarop gewys. 
beteken: „dra mekaar se laste en vervul so die wet van Christus.” Tussen die heidengemeentes en die arm Christene in Judea, wat mekaar nooit gesien het nie, en wat volgens die kerksplitsing in Gal. 2 vermeld, as „heidene" en as „,besnedenes" onder afsonderlike kerkverband ressorteer het, het daar egte, Bybelse, koinonia bestaan, gefundeer in hulle gemeenskaplike gehoorsaamheid aan die gebod van die liefde, „, die wet van Christus." Só stel Paulus dit ook in Rom. 15:20-24.

Nog 'n enkele verwysing, na Joh. 17, die hoëpriesterlike gebed van Christus, mag hier op sy plek wees. Hierin bid Christus vir die eenheid van die kerk. Hierdie eenheid omsluit nie alleen alle gelowiges in die ruimte nie, maar veral ook alle gelowiges in die tyd. „Ek bid nie vir hulle alleen nie, maar ook vir die wat deur hulle woord in My sal glo." (vers 20) Voor Hom, om Hom geskaar, sien Christus elf dissipels staan; maar agter hulle sien $\mathrm{Hy}-\mathrm{Hy}$ sien dit!- die gestaltes opdoem van die miljoene wat oor die baie eeue wat kom, deur hulle woord, die getuienis van die N.T., in Hom sál glo. Hy sien hulle almal om Hom geskaar, en $\mathrm{Hy}$ bid dat hulle één sal wees, één in die geloof in Hom wat in hulle midde staan. Kan dit, die eenheid van die kerk in die wêreld óór die eeue sigbaar gemaak word in die wêreld $?^{26}$ ) Netso min as die eenheid wat „dáárin bestaan dat „U, Vader, in My, en Ek in U" is, en netso min as die eenheid wat daarin bestaan ,dat hulle in Ons een is"! Nie om dowe neute bring Christus hierdie drie verhoudings in verband met mekaar nie. Die eenheid van Vader en Seun, die eenheid van Christus en gemeente, en die eenheid van die kerk oor die aarde en oor die eeue, word as geskenk ontvang en gegló, nie as prestasie gemáák en gedemonstreer nie! Daarom bíd Christus daarvoor! En dat die bietjie wat daarvan tereg kom, daartoe sal lei, ,dat die wêreld kan glo”, dáárvoor bid Hy ook. Dís die troos van die kerk in die aanvaarding van sy sendingtaak. Daarom het die Kerk die vrymoedigheid van die geloof om, wanneer dit móét, deur onderlinge ooreenkoms, op verskillende weë te gaan, en juis sodoende "mekaar die regterhand van gemeenskap te gee."

Móét die eskatologiese waarheid van die eenheid van die kerk dan nóg langer gebruik word om aksiomaties aan te toon dat die benadering van die rassevraagstuk deur kerk en owerheid in Suid-Afrika, ipso facto onbybels is? Is dit nie veel eerder so nie dat „die owerhede en die magte in die hemele", by die kerk moet verneem dat die wysheid van God nie enkelvoudig is nie; nie net één gestalte het wat oral en altyd star en wetmatig dwingend geld nie, maar dat dit in teendeel polupoikilos (Ef. 3:10) is, met ander woorde veelvuldig, veel vorms en gestaltes, letterlik veel „kleure” (sic) kan aanneem? En gaan dit dan nou nie in hierdie skrifgedeelte juis dáárom om ,vir almal aan die lig te bring wat die huishouding is van die geheimenis wat in God VERBORGE is"; , ,die GEMEENSKAP van die VERBORGENHEID," volgens die Afrikaanse vertaling, nie? Met dit alles is geensins angetoon dat die Bybel die stigting van

26) A. S. Geyser, a.w., bl. 11. 
volkskerke of die respektering van etniese of rassegrense eis nie. Dit was ook nie die bedoeling nie. Verre daarvandaan! Maar netso min verbied die Bybel dit! Hieroor skryf Strathmann onomwonde onder laos in T.W.N.T. Wat hopelik gesuggereer is, is dat die kerk in SuidAfika enige grond hét vir sy versoek aan die kerk in die wêreld om 'n ge-opende oog te hê vir die gans-unieke situasie waarin die kerk hom in Suid-Afrika bevind, asook vir sy versoek om as Blanke én nie-Blanke kerke hiér, in die vryheid van die kinders van God, voor owerheid en volk te mag lewe op 'n wyse wat meen om voor God te kán verantwoording aflê aangaande die heil van alle mense in Suid-Afrika, in die hede, maar ook in die toekoms.

\section{Kerk en Owerheid in Suid-Afrika en die Buitewêreld}

Wat kan van die kerk in Suid-Afrika in sy optrede teenoor die owerheid in Suid-Afrika verwag word? Sekerlik dat hy van die owerheid die be-oefening van goeie politiek sal eis, dit wil sê politiek wat ten opsigte van die rassevraagstuk in Suid-Afrika die voortbestaan van wet en orde met die verwesenliking van die hoogs-moontlike mate van reg en vryheid vir alle mense sal bevorder; en dat hy dan verder van die owerheid, in 'n uiters-ontplofbare situasie, die allermenslikste en die allersimpatiekste optrede teenoor elke afsonderlike mens in die toepassing van hierdie politiek sal eis; tegelykertyd sal hy van die ganse volk maar ook van anders, begrip en lojaliteit, en die afstand van alle kortsigtige en selfsugtige oorwegings van eie belang, eie bevoorregte posisie, eie gemak en gerief, én die aanvaarding van medeverantwoordelikheid vir die welslae van hierdie goeie politiek, eis.

En as daar nou 'n owerheid gevind kan word wat, in die angesig van titaniese teenstand vanuit binne- en buiteland, gekies het vir wat na die oortuiging van die kerk werklik die enigste goeie politiek is, sou dit nie kon wees dat die kerk dan aan hierdie owerheid voor God bó alles dit verskuldig sal wees, dat hy, in die aangesig van daardie selfde titaniese teenstand, vreesloos sou getuig (marturein) dat hierdie politiek werklik die heil van alle mense die beste dien nie? As „die owerhede, die magte, die wêreldheersers van die duisternis van hierdie eeu, die bose geeste in die lug" (Ef. 6:12) hierdie getuienis van die kerk nie te hore kry nie, van wie móét hulle dit dan hoor? Is dit nie só dat „,nou deur die gemeente aan die owerhede en magte in die hemele die VEELVULDIGE wysheid van God bekendgemaak (moet) word" (Ef. 3:10) nie?

Moet die reeds-aangehaalde woord van Barth, in die algemeen gesproke, nie met besondere skerpte op hierdie situasie toegepas word nie? „Van alle ander kante af kan die owerheid, en kan elke afsonderlike owerheid met sy bemoeienis om menslike reg grondig geproblematiseer word. Van die kant van die kerk af kán dit nie gebeur nie ..."27) Of ook: „Sê dié Skrifwoord (I Tim. 2:1-6) eintlik minder as dit: „Dat die

27) K. Barth, a.a.O., S. 39. 
kerk nie net sydelings nie, nie net in één van sy funksies naas andere nie, maar in die ganse handele waarin hy as kerk bestaan, soos vir alle mense, só gans-besonders vir die draers van die staatsgesag voor God moet instaan? Instaan, dit wil sê - want dit beteken die huper tog - in hulle plek die aanroeping van God voltrek, wat hulle nie self kán voltrek nie, miskien ook nie wíl voltrek nie, en wat tog voltrek móét word. Hulle kan hulle regeringsmag WAT VIR DIE KERK SO HEILSAAM IS, en wat terwille van die prediking VIR ALLE MENSE SO ONONTBEERLIK IS, immers alleen van God af verkry en behou. Verre daarvandaan dat die owerheid voorwerp van aanbidding kan word, het hy en sy verteenwoordigers en draers veel méér juis behoefte daaraan dat vír hulle gebid word ...."28).

En as die kerk voor God moet instaan vir die owerheid, sou dit kon wees dat hy met enige goeie reg die veel- ligtere verpligting mag ontwyk om ook voor die wêreld - en as dit móét ook voor die kerk in die wêreld - vir daardie owerheid in te staan?

Sou dit kan wees dat van alle instansies en alle sake in die wêreld, alleen die owerheid in Suid-Afrika nie die reg het om, wanneer hy dit nodig het, van die kerk te verneem: „,Salig is julle wanneer die mense julle beledig en vervolg, (Is boikot nie vervolging nie?) en valslik allerhande kwaad teen julle spreek om My ontwil", nie? En as dit nou gaan om die behoud van ,'n rustige en stil lewe... dat alle mense gered kan word", gaan dit dan nie „om My ontwil" nie? En as dit nou dalk só was dat die owerheid in Suid-Afrika dit móés hoor, dat dit dalk eendag duidelik word dat dit ter wille van alle mense, in Suid-Afrika; in dié hele groot, droewe en dreigende Afrika! in die hele 20ste eeuse wêreld met sy woelende maling van volkere en rasse en kleure, volstrek onontbeerlik was dat die owerheid in Suid-Afrika dít te hore sóu kry, en dat daar in die ganse wêreld geen enkele kerk te vinde was wat die geloof gehad het om hom dit te sê nie? As hy dit van die kerk nie hoor nie, hoe sal hy dit hoor? As die kerk in Suid-Afrika hom dit nie sê nie, watter kerk sál hom dit sê?

\section{Die Тоекомs}

In die hierin-dikwels-gebruikte sinsnede ,permanente samelewingspatroon" sien die ,permanent" op ,,samelewing” en nie op ,patroon” nie. Dit wil die voortdurende saam-verkeer van Blank en nie-Blank in Suid-Afrika beklemtoon teenoor die verdwyning van die Blanke uit ander Afrikagebiede. Ten opsigte van die ,patroon" is ,,permanent" relatief, dit wil sê in relasie tot die veranderende situasie van Blank en nie-Blank in Suid-Afrika. Want in hierdie sin is ook eiesoortige ontwikkeling ' $n$ oorgangsantwoord op die rassevraagstuk in Suid-Afrika, dit wil sê 'n antwoord op die vraagstuk van die saam-verkeer in één land van verskillende rasse wat van mekaar geskei is deur baie eeue kultuur en beskawing en geloof.

28) K. Barth, a.a.O., S. 34 . 
„Eiesoortige ontwikkeling" is die antwoord op dié rassevraagstuk in Suid-Afrika wat ook 'n kultuur- en geloofsvraagstuk is. Dat hy in die toekoms sal ophou om ook 'n kultuur-en geloofsvraagstuk te wees, met ander woorde dat daar ' $\mathrm{n}$ dag sal kom wanneer die afstand tussen Blank en nie-Blank wat kultuur, beskawing en geloof aanbetref, oorbrug sal wees, is deel van die verantwoordelikheid van kerk en owerheid in Suid-Afrika. Hierdie verantwoordelikheid wil eiesoortige ontwikkeling as samelewingspatroon dien.

Wanneer hierdie verantwoordelikheid nagekom is, het eiesoortige ontwikkeling sy doel gedien. Rasseskeiding hoef nie tot in der ewigheid in Suid-Afrika beoefen te word nie. Wanneer die rassevraagstuk in Suid-Afrika opgehou het om ook 'n kultuur- en geloofsvraagstuk te wees, wanneer die rassesituasie in Suid-Afrika by benadering, dit wil sê afgesien van getalsverhoudings, vergelykbaar geword het met die huidige in die V.S.A., dan hou integrasie vir weinig wat werklik kosbaar is, nog 'n gevaar in.

Teen daardie tyd sal 'n ander, nuwe, hopelik wyser, geslag Blankes én nie-Blankes dan saam beslis oor die samelewingspatroon wat dán die heil van alle mense in Suid-Afrika die beste sal dien. Maar óf dit wel 'n wyser geslag sal wees, hang onlosmaaklik daarvan af of Blank én nieBlank intussen daarheen ontwikkel. En dit beteken, na ál die lig wat in 1960 beskikbaar is, dat die opgehoopte wins van die afgelope milennia van ,ontwikkeling" nie paniekerig weggegooi word nie, maar gelowig bereilig, en VOORT-DUREND bewaak, en uitgebou en toeganklik gemaak word. Maar dit is ,eiesoortige ontwikkeling”.

C. L. v. d. BERG. 